دور المزارعات الريفيات المعيلات فى إدارة أزمة جائحة فيروس كورونا (كوفيد - 9 (1) بإحدى قري منطقة وادى الصعايدة بمركز إدفو محافظة أسوان

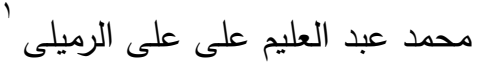

بالاعتماد على المخزون من السلع والأموال لايهن، وتسويق منتجاتهن فى منازلهن، والاعتماد على مواردهن الذاتية فى تقليل

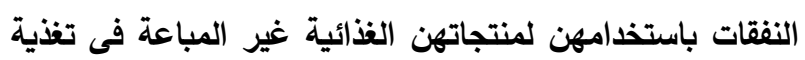

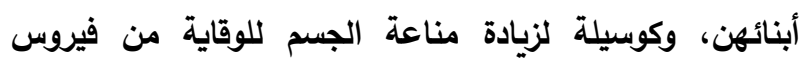

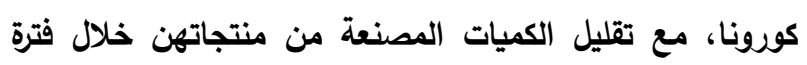
الحظر، والاعتماد على أفراد أسرتها فى تنفيذ الأعمال المزرعية، وذلك لإحتواء الأضرار الاقتصادية. وللحد من الأضرار الاجتماعية قمن المبحوثات بإستخدام الهواتف للتواصل مع الأهل والأصدقاء بلاًا من التواصل المباشر بهن، وللحد من الأضرار الصحية قمن الصن

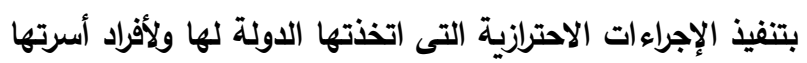
من الالتزام بساعات الحظر، وعدم الذهاب لأسواق القرية، وعدم

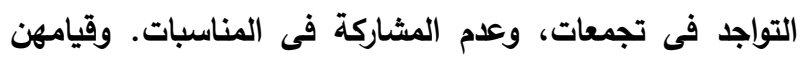
بالممارسات اليومية للعودة إلى أنثطتهن اليومية، واحتواء أضراد

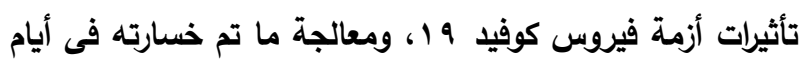
الحظر، مع تطبيقهن لنفس إجراءاتهن وممارستهن فى مرحلة

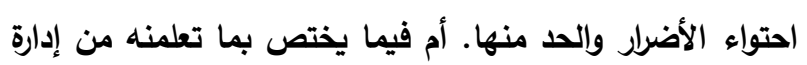
الأزمة فكانت المواظبة على النظافة الشخصية واستخدام المنظفات والمطهرات، ولبس الكمامة، وتقديم الوجبات والأغذية

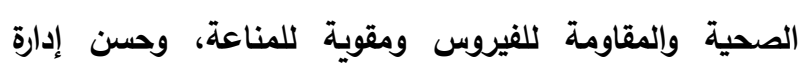

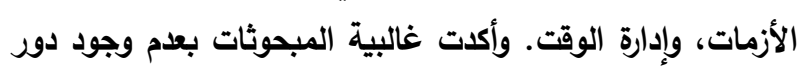
يذكر لجهاز الإرشاد الزراعى والمنظمات التنموية بقريتهم خلال دورة الأزمة وإدارتها.

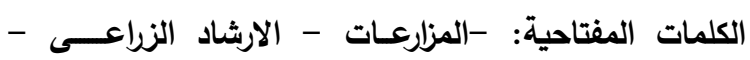

ادارة الأزمات - المقابلة المتعقة : العزارعات
الملخص العربى

استهاف البحث التعرف على دور المزارعات الريفيات

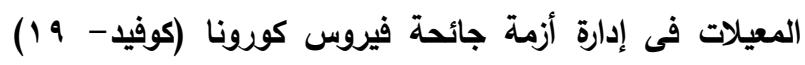

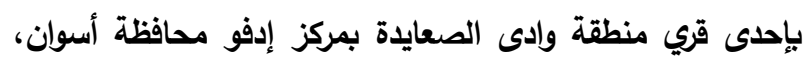
وقد جمعت بيانات البحث باستخدام دليل المقابلة بإجراء مقابلات

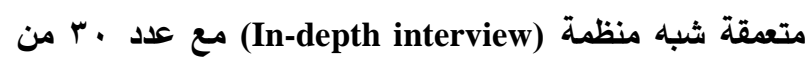
المزارعات الريفيات المعيلة تم اختيارهم بطريقة عمدية انتقائية

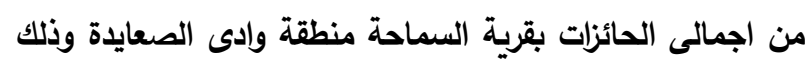

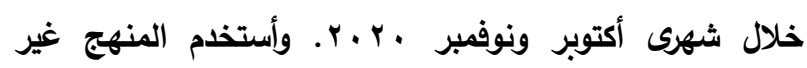
الكمى فى تحليل بيانات البحث، وتلخصت أهم نتائج البحث فى البهي:

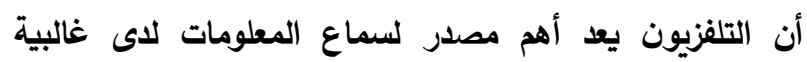

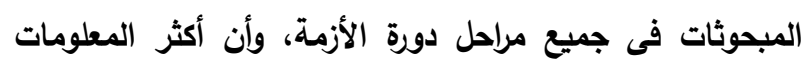
التى تعرضن لها تتعلق بكيفية تجنب الأصابة وأساليب الوقاية

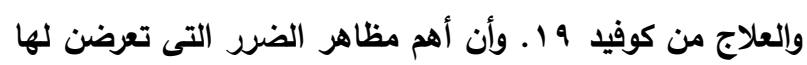

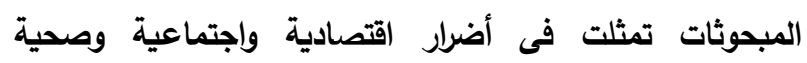

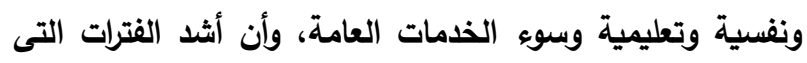

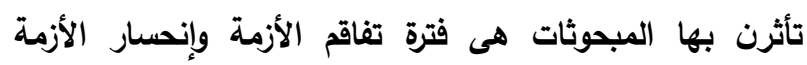

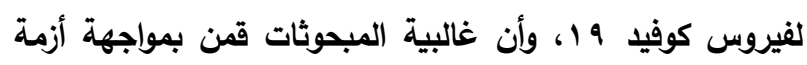

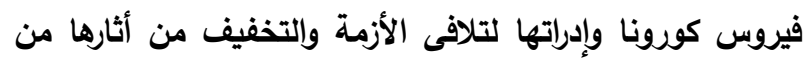

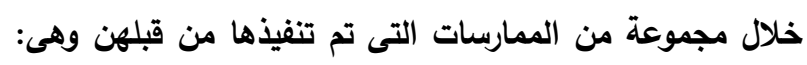

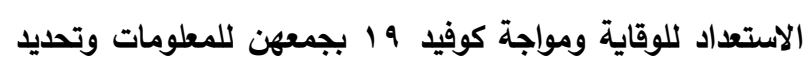
أضراره ومكمن خطورته وذلك فى مرحلة الإكتشاف والإنذار المبكر

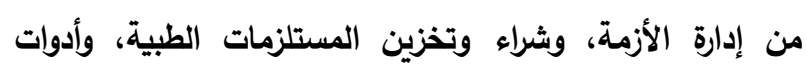
التعقيم، والتتظيف وذلك فى مرحلة الاستعداد واللوقاية من وناك

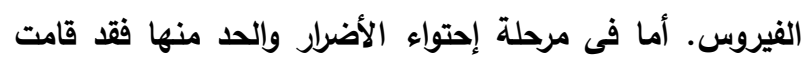

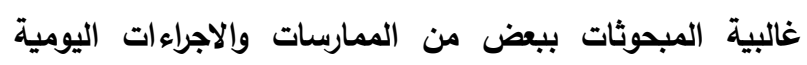

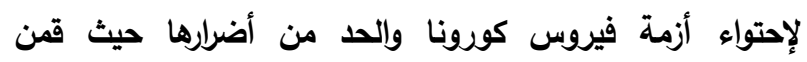

' قسم الإقتصاد الزراعى - كلية الزراعة- جامعة بنى سويف Elramily2011@yahoo.com

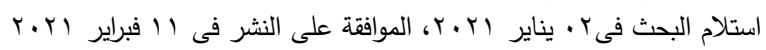




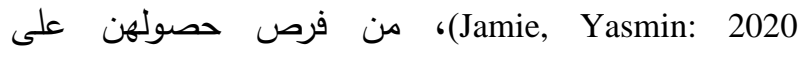
المدخلات الانتاجية والتسويقية والتمويلية والخدمات الإرشادية Alison, ) والاتصالية، مما يتسبب فى إنخفاض دخلهن Patricia, Joao: 2020 واللجوء لببيع بعض ممتلكاتهن أولاً

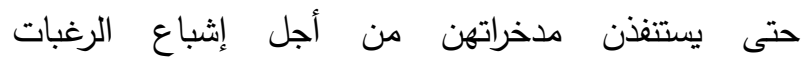
والاحتياجات الضرورية من الطعام والضروريات الأخرى لهن هن ولأفراد أسرهن (FAO,2020:1-10).

وكثفت أزمة جائحة فيروس كورونا التى تمر بها دول العالم الأن عن العديد من مظاهر القوة والضعف لإمكانيات الدول فى مواجهة هذه الأزمة، فمنذ الإعلان عن ظهور الإن الزه

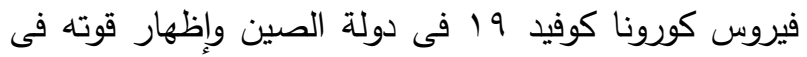
إصابة الملايين من البشر، مع ازدياد فى أعداد الوفيات

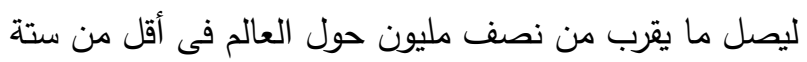
أشهر منذ ظهوره. وما تبعه من اضطرابات اقتصادية على ملى هلى مستوى دول العالم مما تسبب فى إغلاق بعض الدول على وملى له

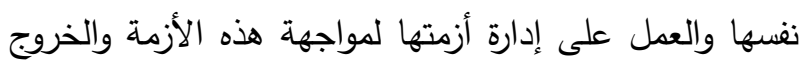

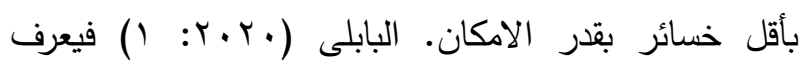

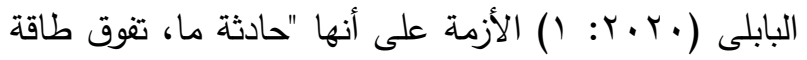
المؤسسة أو المنظمة، أو الدولة، وتحتاج إلى تضافر لجهود لأدارتها، وهى تولد كبيرة وتتتهى صغيرة." وللأزمات بعض من السمات والخصائص يمكن ايجازها فى نقص البيانات والمعلومات المتاحة أثناء حدوث الأزمة، والمفاجأة فى حدوثها، وتصاعد الأحداث وتعقدها وتداخل

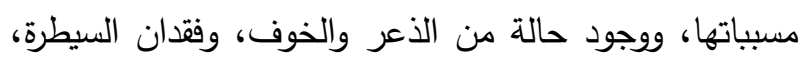

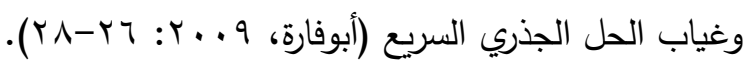
وتمر الأزمة بخمس مراحل، الأولى: وهى مرحلة الميلاد وتسمى مرحلة الانذار المبكر فتظهر الأزمة بشكل مبهم لأول

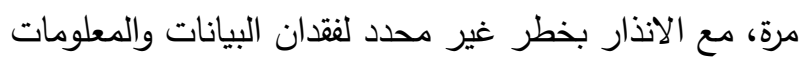

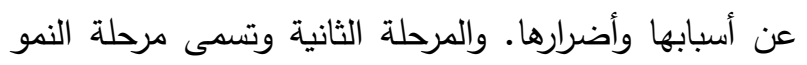
وفيها يزداد الاحساس بالازمة لسوء الفهم فى المراحل الأولى ولى ولى ولى من ميلادها، ثم مرحلة النضج ويحدث فيها تطور للأزمة،

\section{المقدمة و المشكلة البحثية}

تسبيت جائحة فيروس كورونا COVID-19 في حدوث صدمة عميقة في جميع أنحاء العالم، كما شكلت تهديداً خطيراً لحياة أهل الريف وسبل معيشتهم، وعلى مشاركتهم فى الأنشطة الاقتصادية والاجتماعية بمجتمعاتهم الريفية كزارع أو أو الرئي عمال زراعيين أو كوسطاء وتجار أو مصنعين للمواد الغذائية. وما قد ينتج عن ذلك من خسائر كبيرة فى دخولهم

(FAO,2020:1-10)

وارتباطاً مع عواقب ما حدث من أزمات عالمية سابقة

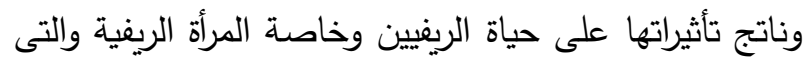

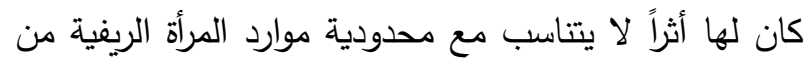
ملكية الأرض الزراعية، والحصول على مستلزمات الأنتاج الزراعي كالأسمدة والتقاوى، بالإضافة إلى محدودية الحصول

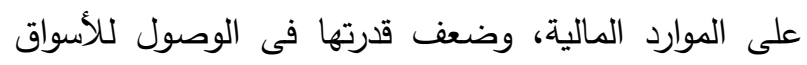
للحصول على الموارد اللازمة لتحقيق الأمن الغذائى لها ولأسرتها، وضعف الخدمات الصحية، وكذلك فرص الحصول على تعليم مميز فى بعض ولى المناطق الريفية. (الأمم

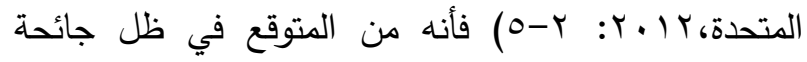
فيروس كورونا إنحسار دخول النساء والفتيات بشكل عام، والريفيات على وجه الخصوص، مع الحرمان من الخدمات

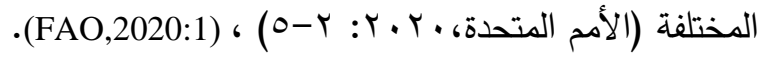
وحيث أن المرأة الريفية تواجه في حياتها اليومية تحديات متتوعة خلال ساعات عمل تتراوح من 17 إلى 11 ساعة

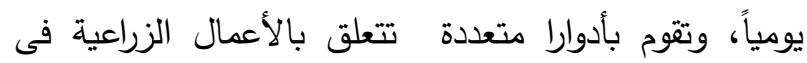

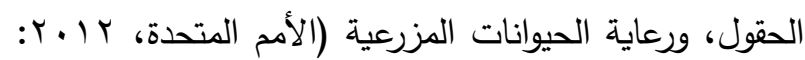
ب-7 ( )، بجانب أدوار إجتماعية بتحمل مسئولية رعاية أفراد أسرتها من الصغار وكبار السن، ومهام منزلية بإعداد

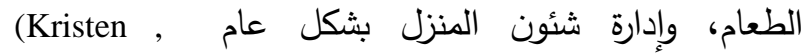
.Jenn, 2020)

وفى ظل تلك التحديات التى تواجهها المرأة الريفية المعيلة جعل من الصعب عليها القيام بعمل بديل أو أداء أعمال

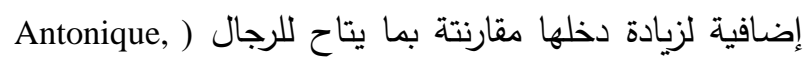


189 محمد عبد العليم على على الرميلى.: دور المزارعات الريفيات المعيلات فى إدارة أزمة جائحة فيروس كورونا (كوفيد -9 ()............

والتى كانت تختلف عن الأزمات فى الماضى من حيث المفاجئة فى حدوثها بشكل غير متوقع وغير مسبوق بالإضافة إلى طبيعتها العابرة لحدود (مركز البحوث

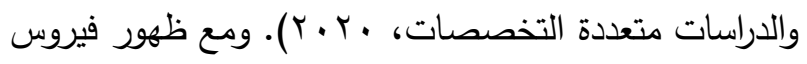
كورونا والبدء فى الانتشار للمرة الأولى في مدانى مدينة

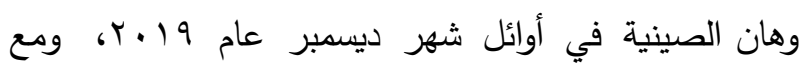

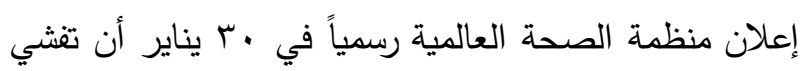

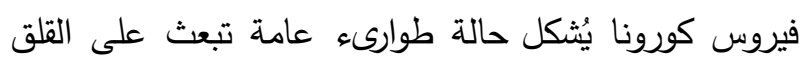

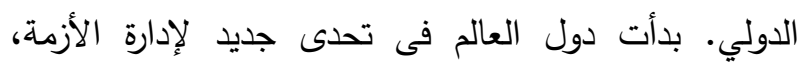

لتلافى الآثار السلبية على جميع القطاعات الحيوية. وفى جمهورية مصر العربية بدأت إدارة أزمة جائحة فيروس كورونا من خلال ما اتخذه مديرى الأزمة من إجراءات الحماية الاجتماعية وما تبعه من اتخاذ اجراءات احترازية للحد من انتشار فيروس كورونا وآثاره من حظر منزلى،

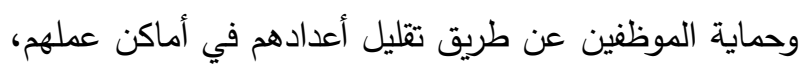
وغلق جزئى للمحال التجارية، والأسواق، وتحديد ساعات لسير وسائل النقل والمواصلات بين المحافظات (الهيئة

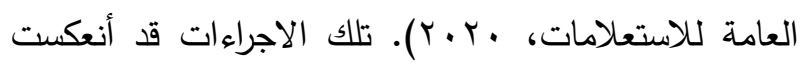

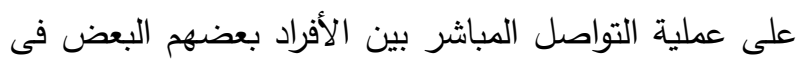
مختلف المجتمعات ومنها المجتمع الريفى الزراعى فحدث تباعد وعدم اتصال مباشر ما بين الزراع وبين بعضهم البعض البرات من جهة، ومابين الزراع وبين أجهزة الإرشاد الزراعى والأجهزه

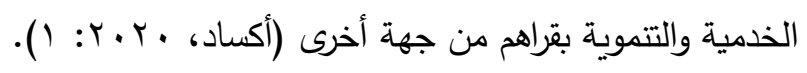
يجب إدراك أن أنتشار الأوبئة فى الريف لا يمثل أزمة صحية وأزمة اقتصادية فقط، بل يمثل أيضاً أزمة أمن غذائي تؤثر على كل من الرجل، والمرأة فى الريف. إلا أن للمرأة الريغية دور معترف به في ضمان استدامة الأسر والمجتمعات الريغية وتحسين سبل المعيشة الريفية والرفاهية العامة، لما تمتلكه المرأة الريفية لمعظم المعارف الضرورية للحفاظ على لرئ الأمن الغذائي، فهن وريثات المعارف التقليدية والقائمات
وتسمى بمرحلة الإنفجار · والمرحلة الرابعة وهى مرحلة

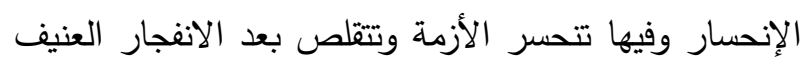

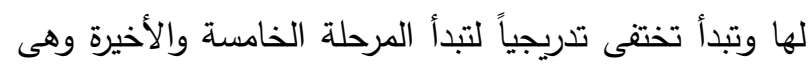
مرحلة التلاشى والتى يحدث للأزمة فقدان كامل لقوتها وتتلاشى مظاهرها وتأثيراتها وتتتهى معها مرحلة الهلع

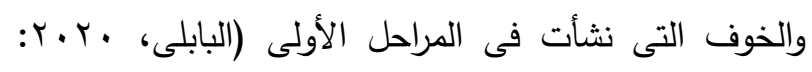
وقد حدد المركز المصرى للدراسات الاقتصادية (•r.r.r.

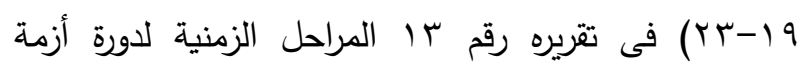
كورونا وهى مرحلة ظهور الفيروس (من ديسمبر 9 1 ـ ليناير

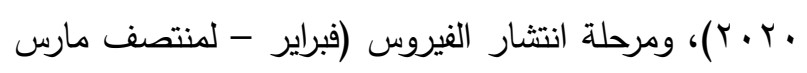

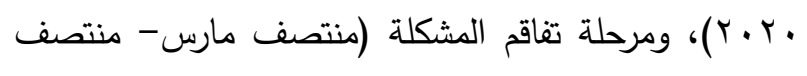

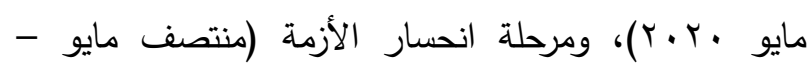

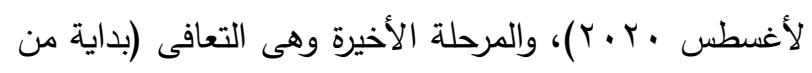

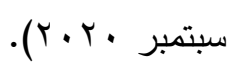

ولتلافى الأزمات والتخفيف من أثارها والعمل على إعادة

الأوضاع إلى ما كانت عليه قبل وقوع الأزمة فلابد من استخدام اساليب محددة ومنهجية يتم من خلالها إدارة الأزمة.

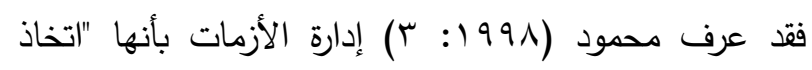
إجراءات طارئة تحت ضغوط متتوعة ومتعددة وتوتر داخلى لحل مشكلات سبيتها الأزمة نفسياً إما بفعل أو تصدير جانب آخر وإما بتراكم آثار وسلبيات البيروقراطية والإهمال

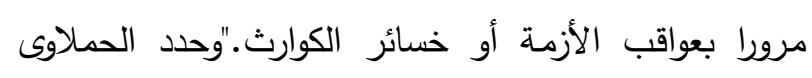

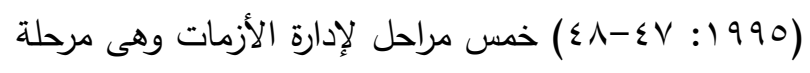
إكتشاف إثارات الانذار، ومرحلة الإستعداد والوقاية، ومرحلة

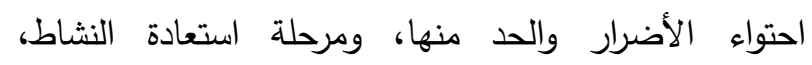
والمرحلة الأخيرة وهى مرحلة التعلم. تحدت الأزمات فى الفترة الأخيرة منذ بداية القرن الحادى والعشرون مديرى المخاطر فى العديد من بلدان العالم بسبب

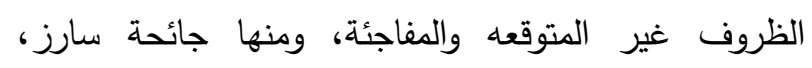

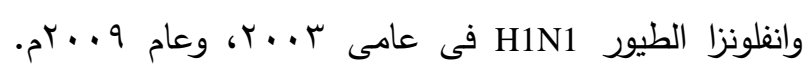


9 1" للتعرف على احتياجات النساء الريفيات، ومعرفة دورن

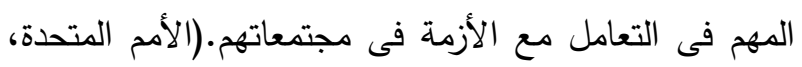

$(r \cdot r$.

وبأستعراض البحوث والدراسات العلمية فى مجال العمل الإرشادى الزراعى التى تتاولت تداعيات جائحة فيروس كوفيد 19 على المجتمع الزراعى المصرى بشكل عام تبين وجود

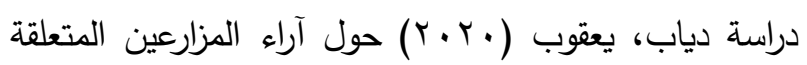

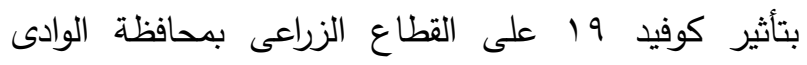
الجديد، مصر، ولكن لم تتتاول البحوث فى مجال العمل الإرشادى الزراعى الآثار الاجتماعية والاقتصادية، فى كيفية

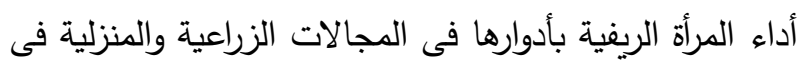
ظل جائحة COVID-19 وتدابير احتوائه فى حدود علم الباحث حتى الآن. لذا فقد أجرى هذا البحث لمعرفة دور المزارعات الريفيات المعيلات أصحاب الحيازات الزراعية

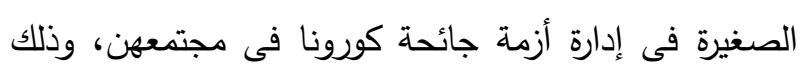

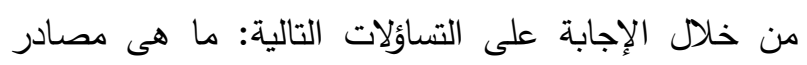
معرفة المبحوثات بفيروس كورونا، وما هى مظاهر التأثر

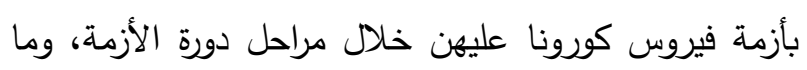

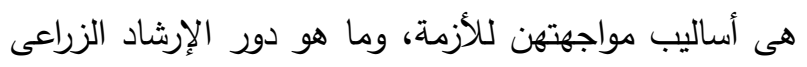

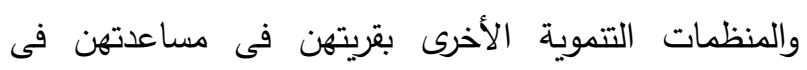
مواجهة أزمة جائحة فيروس كورونا. حتى يمكن الاستفادة منها فى وضع برامج إرشادية متخصصة للريفيات المزارعات، وكيف يمكن استغلال هذه الجائحة واعتبارها فرصة يمكن برانج اغتتامها لإتاحة القرار أمام جميع الأجهزة المعنية لتمكين المزارعات الريفيات المعيلات من اكتساب القدرات الكافية للقيام بدورهن الايجابى للخروج من الأزمة الحالية وبشكل خاص صمودهن ومواجهتهن للأزمات الكبرى مثل كورونا مستقبلاً.

\section{الاهداف البحثية}

واتساقا مع مقدمة البحث ومشكلته يهدف هذا البحث إلى

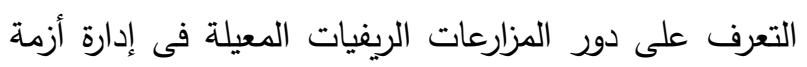

على استغلالها، بما في ذلك كل ما يتعلق بقدراتها على

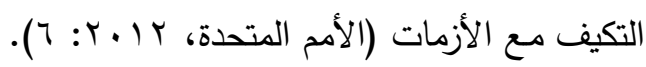
وحتى تتمكن المرأة الريفية من القيام بأدوارها فى لـ

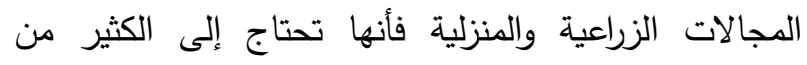
المعلومات التى لا تكتسب تلقائياً بل من خلال برامج إرشادية

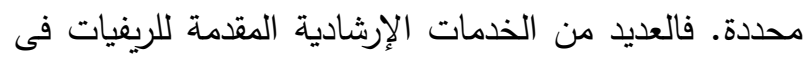
القرن الماضى كانت تركز على التربية المنزلية والتغذية للأسرة الريفية فقط، حيث كان ينظر للمرأة الريفية على أنها زوجة المزارع farm wives وليس كإمرأة مزارعة farmer Davis, K., S. C. Babu, and C. Ragasa,2020: ) women

لذا فيجب على الجهاز الإرشادى الزراعى أن يضع المزارعات فى بؤرة اهتمامه، وأن يقدم المعلومات لهن باعتباره الجهاز المسئول عن الاحتياجات التعليمية والتدريبية لجمهوره

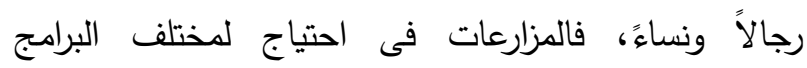
الإرشادية الزراعية، فهن يحتجن إلى برامج إشادية زراعية

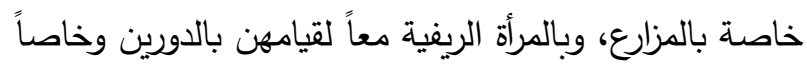
لمن تدير أرضها الزراعية ولا يوجد لها معيل بل هى من تعيل الأسرة، وكذلك مزارعات المناطق النائية يحتجن أكثر إلى لى برامج إرشادية زراعية لتخفيف عبء الرعاية. ونظراً لما تواجهه المرأة الريفية من قيود في الوصول إلى الموارد الإنتاجية والخدمات والتثنيات والأسواق والأصول المالية والمؤسسات المحلية، فيجعلها أكثر عرضة لآلثار Alison, Patricia, Joao: ) COVID-19 فيروس كورونا 2020)، وكذلك الأسر ذات العائل الوحيد- فى الغالب تكون المرأة هى العائل الوحيد للأسرة- فمن المرجح أن تكون أكثر

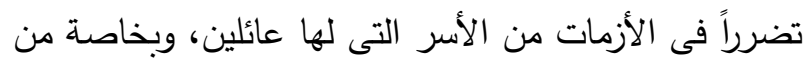
يقدن بالمناطق النائية (10:10:2020:1)، ولإهتمام الأمح المتحدة بالريفيات فى ظل جائحة فيروس كورونا من أجل بل بناء قدراتهن لمواجهتن لجائحة فيروس كورونا قامت الأمم فاتم

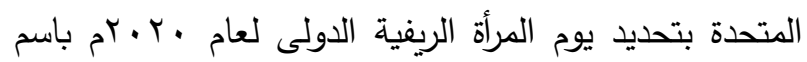
"بناء قدرة المرأة الريفية على الصمود فى أعقاب جائحة كوفيد 
191 محمد عبد العليم على على الرميلى.: دور المزارعات الريفيات المعيلات فى إدارة أزمة جائحة فيروس كورونا (كوفيد -9 ()...............

المعرفة عنهم ومالديهم من خلال الرجال نيابة عن النساء

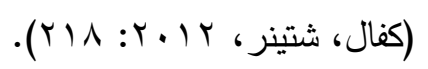

وتتخذ المقابلة المتعقة الفرد كمنطلق للعملية البحثية،

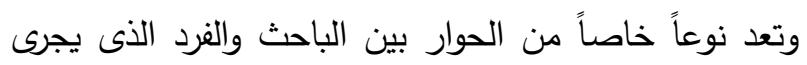
معه الsقابلة. ويعد هذا الأسلوب بمثابة جهد لخلق المعرفة يتم

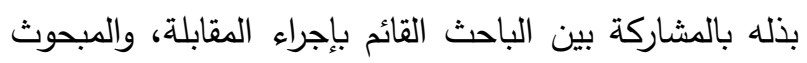
الطرف الذى تجرى معه المقابلة. وتتقسم المقابلات المتعمقة إلى مقابلات مقننة، ومقابلات شبه مقننة، ومقابلات مفتوحة.

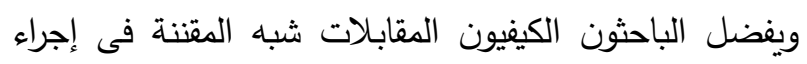

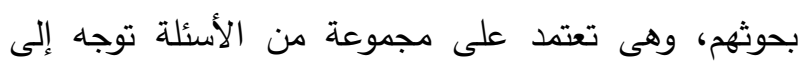

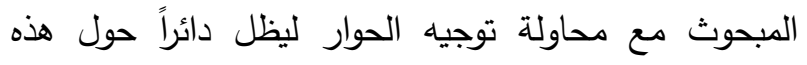
الأسئلة بقدر كبير من المرونة والحرية. ويتيح للمبحوث قدراً

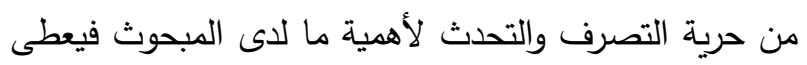

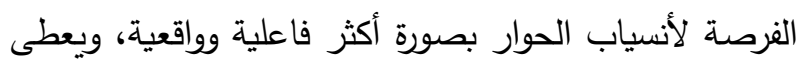

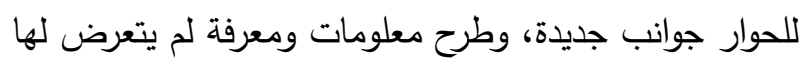
الباحث من قبل. ويمتاز هذا الأسلوب بأنه يسمح للباحث

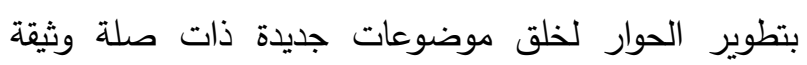
بالبحث والمبحوثين وذلك عند استخدام الباحث تصميماً شبه

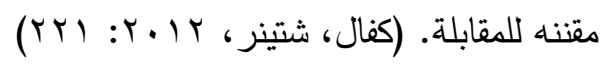

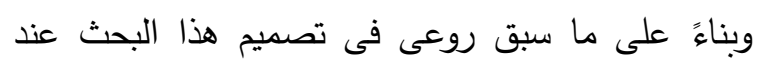
اختيار المبحوثات اللاتى ستجرى معهن الدقابلات المتععقة

$$
\text { على ثلاثة عناصر أساسية وهى: }
$$

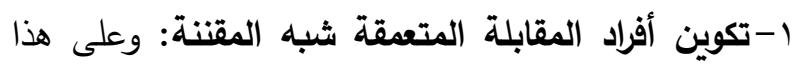
الأساس اشتمل شاملة البحث على المزارعات الريفيات

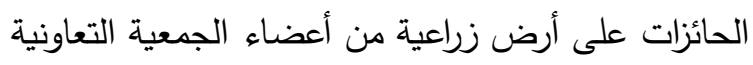
الزراعية بقرية السماحة بمنطقة وادى الصعايدة بمركز أدفو محافظة أسوان، وهن من النساء المعيلات لأسرهن.

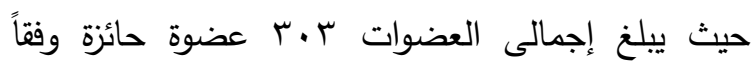
لكثوف الحيازة بالجمعية التعاونية الزراعية.

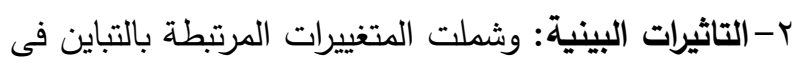
الفروق الفردية من حيث السمات الديموجرافية، وبناءً عليه
فيروس كورونا كوفيد 19 وذلك من خلال تحقيق الأهداف

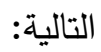

1-التعرف على مصادر معرفة المبحوثات بفيروس كورونا كوفيد 9 ا خلال مراحل دورة الأزمة.

r-التعرف على مظاهر التأثر بأزمة فيروس كورونا كوفيد 19 على المبحوثات خلال مراحل دورة الأزمة.

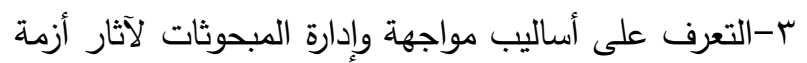
فيروس كورونا كوفيد 9 أخلال مراحل إدارة الأزمة. ع-التعرف على دور جهاز الإرشاد الزراعى والمؤسسات

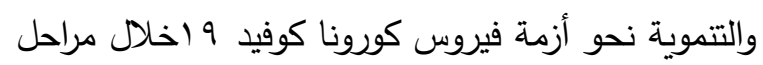

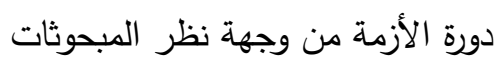

\section{الطريقة البحثية}

أجرى هذا البحث بقرية السماحة بمنطقة وادى الصعايدة

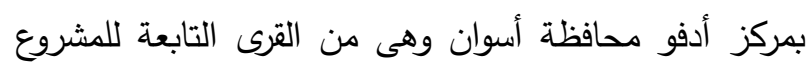
القومى لتتمية وخدمة أراضى شباب الخريجين التابعة لكراقبة

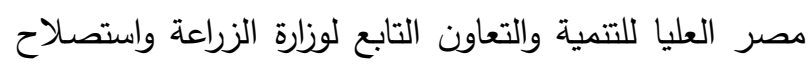
الأراضى والتى أنثئت لإعانة ومساعدة المرأة الريفية المعيلة

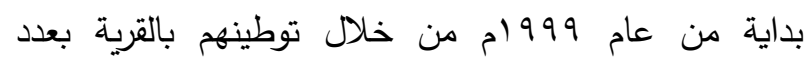

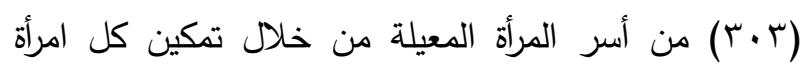
معيلة بستة أفدنة ومنزل للإقامة (وزاره الزراعة واستصلاح

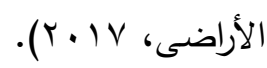

وقد تم جمع بيانات البحث بإستخدام أسلوب المقابلة Semi structured شبه المقنتعة In-depth interview وهى من الطرق المستخدمة فى البحوث الكيفية والتى يسعى

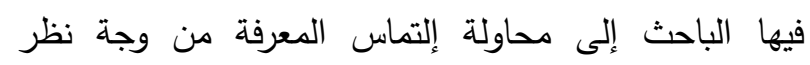

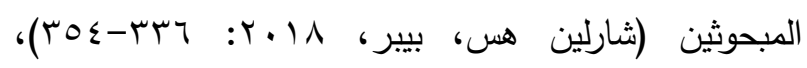
وأسلوب المقابلة المتعدقة من الطرق التى يستخدمها الباحثون

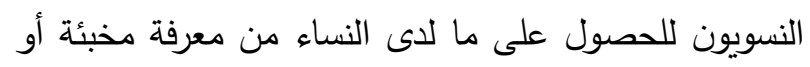

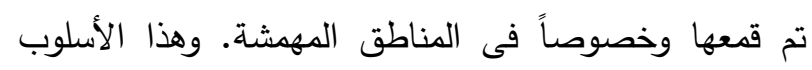

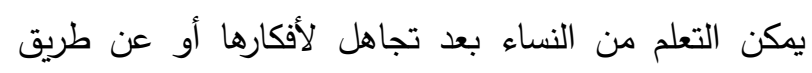


القائم بالمقابلة: تم اختيار منسقة مسئولة عن إدارة الحوار والنقاش فى المقابلة مع المبحوثات، ونظراً لأن المشاركات فى هي

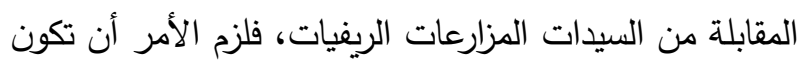

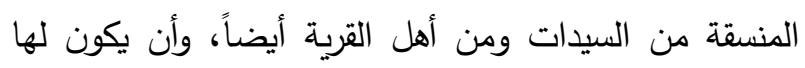
خبرات سابقة فى عمل المقابلات البحثية، وقد قام الباحث بتدريب المنسقة وتعريفها بطبيعة مشكلة البحث، وأيضاً

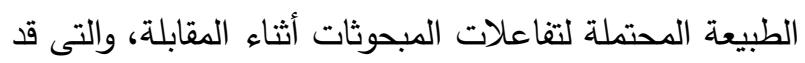
تظهر نتيجة لتركيبة المبحوثات المشاركات، والموضوع محل البحث.

أدوات المقابلة: تم إعداد دليل للمقابلة عبارة عن مجموعة من الأسئلة التى تبحث عن اجابات لتحقيق أهداف الدراسة من خلالها. وقد استعين بتسجيل الجلسات صوتياً بواسطة برامج التسجيل الملحقة بالهاتف المحمول للمنسقة، مع وجود ورقة وقلم لتسجيل الملاحظات والايماءات ولغة الجسد بخط اليد أثناء المقابلة. فقد أكد ) DiCicco -Bloom B, Crabtree BF 2006) بأن المقابلات شبه المنظمة تستند إلى دليل مقابلة شبه منظم، وهو عرض تخطيطي للأسئلة أو الموضوعات وتحتاج إلى استكثافها من قبل القائم بإجراء المقابلة. وتتكون

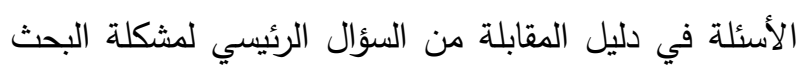

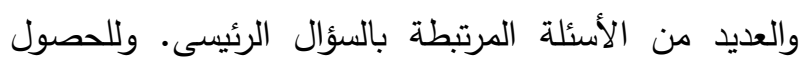

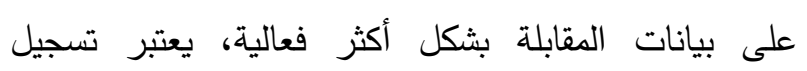
المقابلات اختياراً مناسباً. حيث يُسهل تسجيل المقابلة على لئل منسق الجلسة التركيز على محتوى المقابلة، وبالتالي يُمكن الباحث من إنثاء نص حرفي للمقابلة بعد تقريغها. وقد تم إجراء المقابلات المتعقة شبه المقننة وجمع

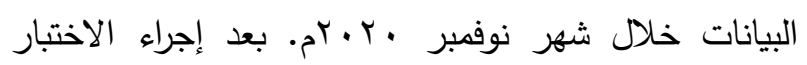
المبدئى لدليل المقابلة شبه المقنتة، والتأكد من سلامة أسئلة الاليل وإجراء التعديلات المطلوبة. وقد تمت المقابلات بشكل منفصل لكل مبحوثة على حده. أدوات التحليل: أستخدم فى تحليل المقابلات شبة المقننة أسلوب التحليلات المتبعة فى تحليل البحوث الكيفية وهى
تم انتقاء المبحوثات من ضمن قائمة كثوف الحائزات

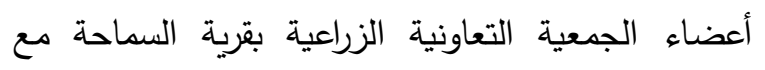
الاستعانة بمسئول الجمعية الزراعية والرائدات الريفيات بالقرية، والمنسقة المسئولة عن إجراء المقابلات المتعمقة. للتأكد من مناسبة كل مشاركة للسمات المحددة للعينة وهى: - أن تكون من الحائزات لأرض زراعية. - أن تكون لها إقامة دائمة بقرية السماحة.

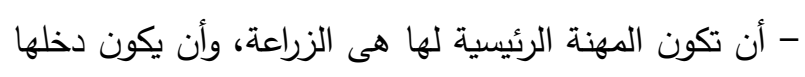
من العمل الزراعى بصفة أساسية. -أن تكون هى العائل الوحيد لأسرتها بأن تكون المرأة أرملة

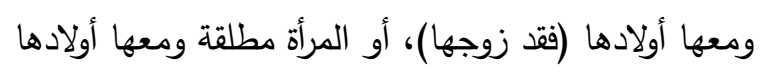

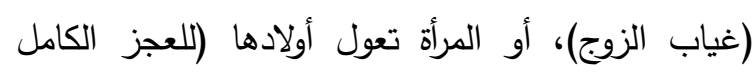
للززوج).

ب-بيئة المقابلة: وقد روعى فى البيئة المادية أن تكون المقابلات فى منزل المبحوثات أو أى مكان آخر تحدده

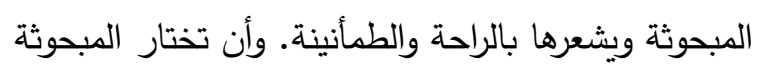

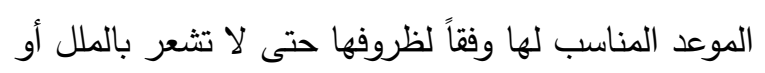
القلق من تأخر أعمال أخرى.

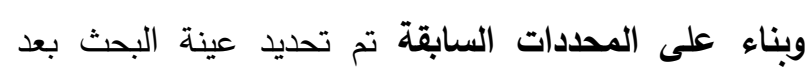
الرجوع إلى سجلات العضوية بالجمعية التعاونية الزرعية

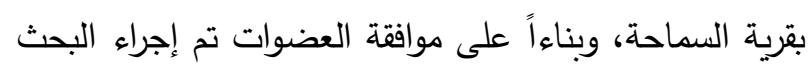
على عدد (·r) ثلاثون مزارعة ريفية معيلة من أعضاء الجمعية واللائى توافقت معهن المحددات السابقة، وهو العدد التى تحقق عنده مرحلة التشبع saturation للبيانات لدى دولى الباحث فى الحصول على بيانات تخدم أهداف البحث وتحقق تحق

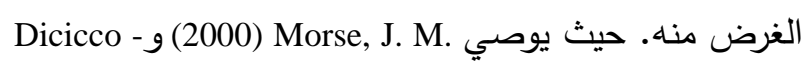

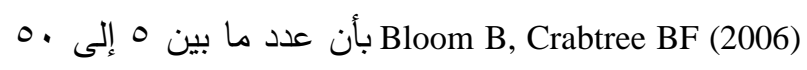

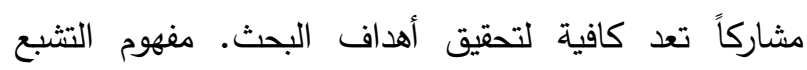
للبيانات the concept of saturation وهى المرحلة التى عند استخدام بيانات مبحوثين أكثر لا تقدم جديد ولا يستفاد منها. 
193 محمد عبد العليم على على الرميلى.: دور المزارعات الريفيات المعيلات فى إدارة أزمة جائحة فيروس كورونا (كوفيد -9 ()......

وكنت بتأخدى معلوماتك عن الفيروس من مين..؟"، وأيه أكتر المعلومات اللى كنتى بتحاولى تعرفيها خلال فترات دورة

الفيروس؟

- مصادر سماع المبحوثات عن فيروس كورونا كوفيد 19 ولقد تبين من نتائج المقابلات أن جميع المبحوثات تركزت مصادر السماع لديهن فى مصدر واحد فقط، حيث ألقابع أقررن

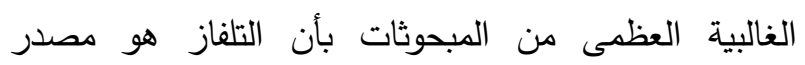

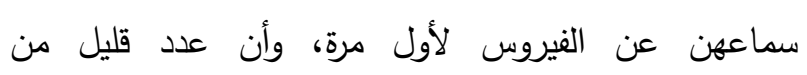

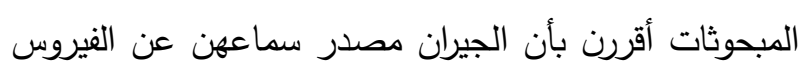
لأول مرة، وتبين ذلك من خلال العبات العبارت التات التى ذكرتها

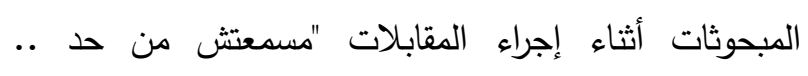

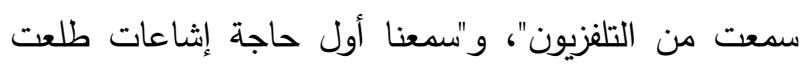

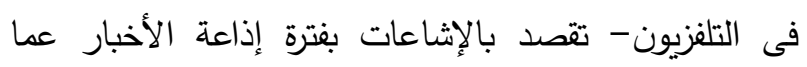
يحدث فى الصين فى بداية انتشار الفيروس- واعتبرتها

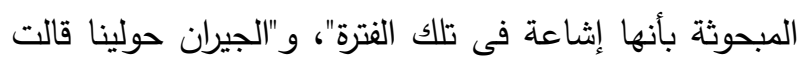
لنا خلى بالك وأنت رايحه السوق لـ (تُلطى) كورونا.. وعرفنا منهم ساعتها أيه هى كورونا". - الفترة الزمنية لسماع المبحوثات بفيروس كورونا كوفيد

وأوضحت النتائج أن الفترة الزمنية لسماع المبحوثات

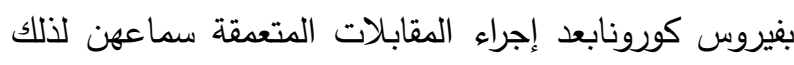

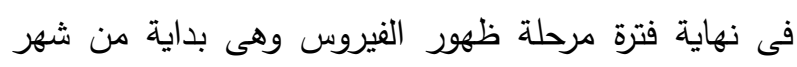

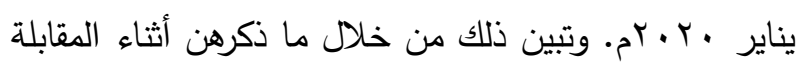

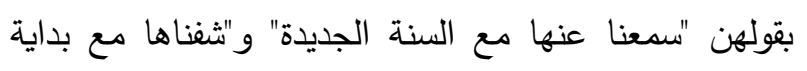

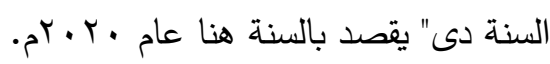

أما الأقلية من المبحوثات فقد سمعن فى فترات متلاحقة دالكنة

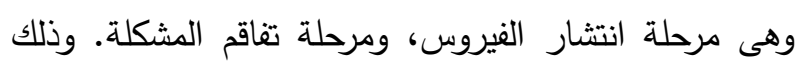

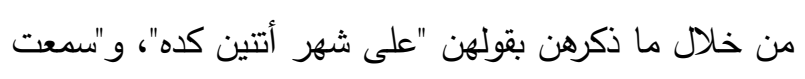

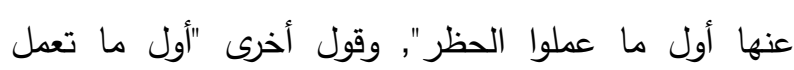

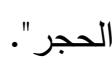

تعتبر عملية تكرارية لجمع البيانات تستمر جنباً إلى جنب مع

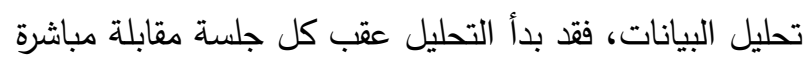
ويومياً ومراجعة البيانات التى تم الحصول عليها من خلاتل تلال الأوراق التى تم تدوين الملاحظات بها من خلانل منسقة التهات

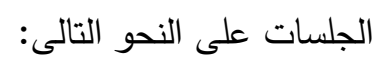

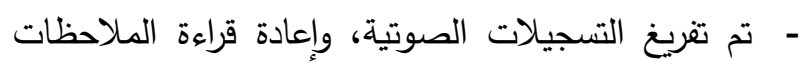
المدونة بخط اليد التى تم أخذها أثناء المقابلات.

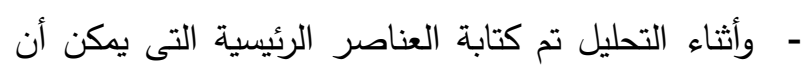

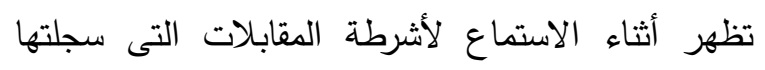

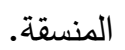

- تم تصنيف المعلومات التى تم جمعها بناء على التى الموضوعات التى تمت مناقشتها من خلال المبحوثات تلمات التى تمت مقابلتهن.

- تم تحديد الأفكار الرئيسية التى تم التعبير عنها لكل موضوع وتحديد أكثر النقاط أهمية وتصنيفيةها.

\section{النتائج والمناقشة}

يتضمن هذا المحتوى عرضاً لنتائج البحث مع توضيح

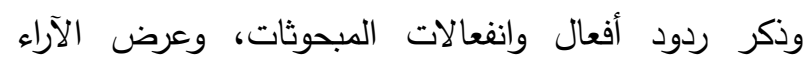

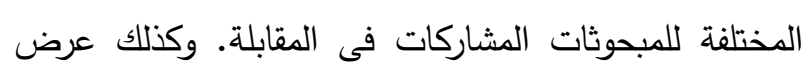
لبعض الجمل والأفكار ووصف للتعبيرات التى أدلت بهات التهات التهات

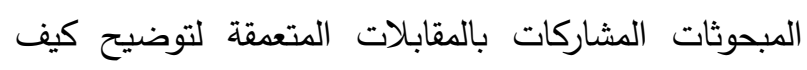
يفكرن، وكيف تصرفن حول موضوع البحث المطروح عليهن.

\section{1 -مصادر معرفة المبحوثات بفيروس كورونا كوفيد 19}

بدأت مناقثة المبحوثات بالتعرف على مصادر سماعهن

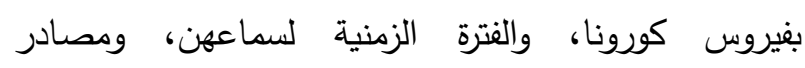

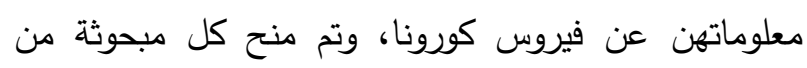

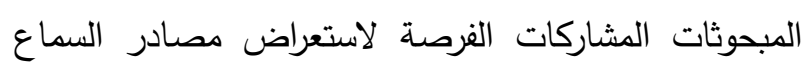

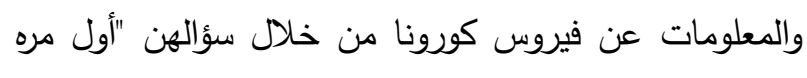

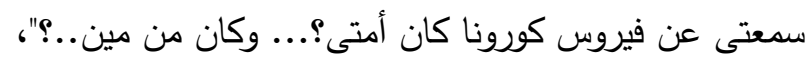


التطبيق، ومحاولة معرفة معدل انتثار المرض وأعداد الإصابات بشكل عام، ومعرفة أعداد من أصيب فى قريتهم على وجه الخصوص، كما أوضحن ذلك خلال مقابلتهن بقولهن: "كنا بنفكر إزاى نحمى نفسنا وعيالنا من المرض"، و و

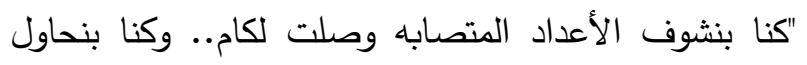
نعرف نحمى عيالنا إزاى"، و "كل شويه نسمع عن حد تصاب لهوه فى البلد ونسأل عليه ونطمن راح لمين؟ أو قابل مين؟ عشان نحرص منه".

ومن العرض السابق نخلص فى أن غالبية المبحوثات قد سمعن عن فيروس كورونا كوفيد 19 فى مرحلة ظهور الفيروس وهى المرحلة الأولى من مراحل دورة الأزمة، وأن فئن فودئ مصدر سماعهن عن الفيروس هو مصدر واحد لاى الغالبية العظمى من المبحوثات، وسيادة مصادر السماع الرسمية (الجماهيرية) لدى المبحوثات وهى التلفاز، ويليها مصادر السماع غير الرسمية وهى الجيران. وأن التلفاز استمر ولاتهات كمدر معلومات فى جميع مراحل دورة الأزمة. وأن أكثر المعلومات تعرض وتتداول بين المبحوثات هى المعلومات همرات المرتبطة بكيفية تجنب الأصابة وأساليب الوقاية والعلاج من فنرضين الفيروس، ومعلومات مرتبطة بسرعة انتشار الفيروس عالمياً

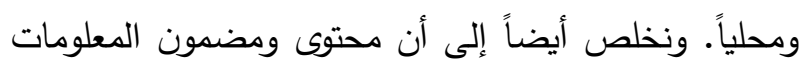
التى يبحثن عنه المبحوثات ويتداولنه فيما بينهن عن الفيروس الفي وندي يختلف بإختلاف مراحل دورة أزمة فيروس كورونا، وذلك يوضح مدى اهتمام المبحوثات بمعرفة كل ما هو جديد عن الفيروس وفى جميع مراحله.

يستتتج مما سبق غياب مصادر السماع الرسمية من قبل الجهاز الإرشادى الزراعى للمبحوثات مثل المرشد الزراعى، والاجتماعات والندوات الإرشادية عن فيروس كورونا كوفيد 9 1 ، وأن المعلومات التى قامت المبحوثات بجمعها وتداولها فيما بينهخ أو ما كانوا يحصلون عليها من مصادرها الرسمية (التلفاز ) لم تتضمن معلومات ومعارف عن كيفية إدارة شئون المنزل والإدارة المزرعية من عمليات زراعية وإنتاجية
- مصادر معلومات المبحوثات عن فيروس كورونا كوفيد

وفيما يتعلق بمصادر حصولهن للمعلومات عن الفيروس وأثاره بعد مرحلة السماع عنه فتمثلت فى التلفاز ، والجيران والأقارب وذلك فى مرحلة انتثار الفيروس، ومرحلة انحسار

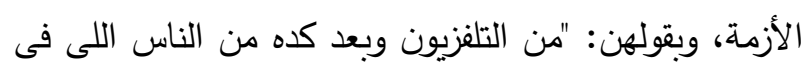
البلد والجيران"، و "كنا بنسمع من التلفزيون وبعد كده الناس وندي فى البلد بقت تتقلها من واحدة لواحدة"، أما فى مرحلة تفاقم المشكلة فكانت مصادر المعلومات تتمثل فى التلفاز فقط كما ذكرن الغالبية العظمى من المبحوثات" بقينا ليل نهار على التلفزيون بنتابعه- تقصد متابعه أخبار الفيروس-", وقول لئن

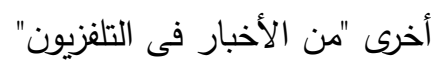

\section{- محتوى المعلومات عن فيروس كورونا كوفيد 19 من} وجهه نظر المبحوثات

وفيما يتعلق بمضمون ومحتوى المعلومات التى قمن المبحوثات بجمعها عن فيروس كورونا فبينت نتائج المقابلات أن الغالبية العظمى من المبحوثات قد أكدن جمعهن لمعلومات عن الفيروس، ومعلومات عن أسبابه وتأثيراته وذلك فى مرحلة نهاية ظهور الفيروس وبداية انتشار الفيروس، وفقاً

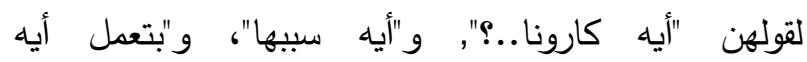
كورونا..؟". أما فى نهاية مرحلة الانتشار وبداية مرحلة تفاقم المشكلة فتمثلت فى جمع المعلومات والمعرفة لدى المبحوثات عن كيفية تجنب الإصابة بالفيروس، وكيفية المعرفة بأنهن قد أصيبوا بالفيروس، وفى حالة إصابتهن كيف يمكنهن مقاومته،

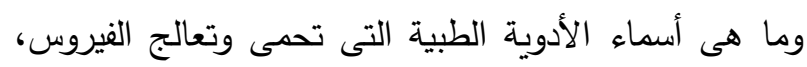
ومحاولة التعرف على أماكن الحصول على المطهرات والكمامات ومعرفة أسعارها، وكذلك محاولة معرفة الوصفات

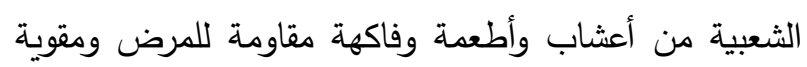

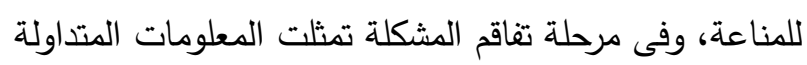

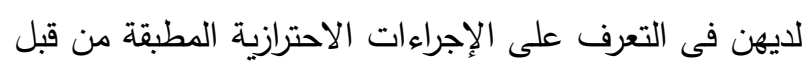

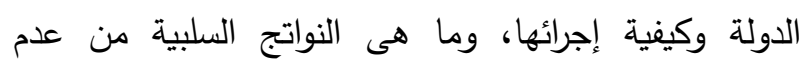


195 محمد عبد العليم على على الرميلى.: دور المزارعات الريفيات المعيلات فى إدارة أزمة جائحة فيروس كورونا (كوفيد -9 ()......

\section{أ- - أ- أضرار اقتصادية}

تبين من نتائج المقابلات المتعمقة أن الغالبية العظمى العيه

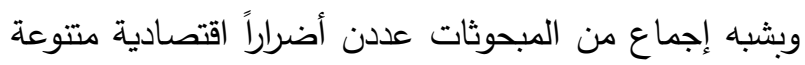

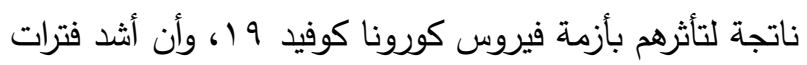

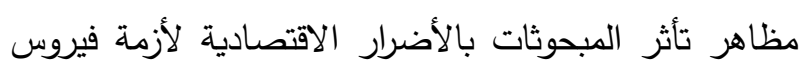
كورونا كوفيد 19 هى مرحلتى تفاقم الأزمة وانحسار الأزمة. وتمثلت مظاهر الضرر فى انخفاض الدخل، مع وزيادة

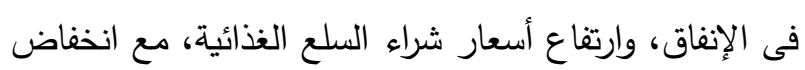

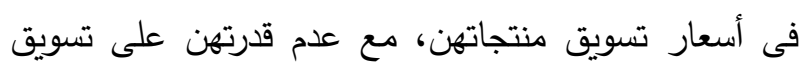
منتجاتهن الزراعية، وعدم قدرتهن على توفير الغذاء بالكميات

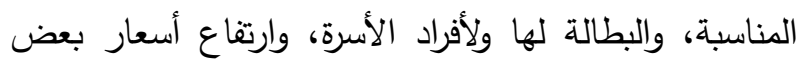

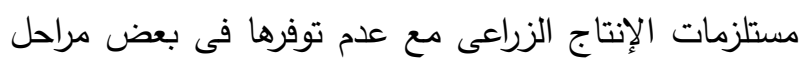

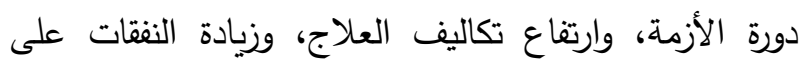
بعض من المشتريات مستحدثة نتيجة للأزمة والتى لم يكن لها

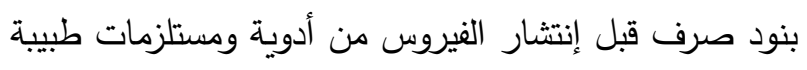

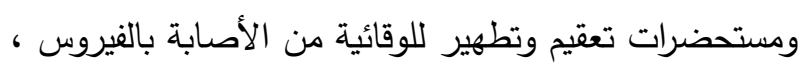
وحدوث فاقد فى الدصصول الزراعى بثقيه النباتى والحيوانى والداجنى، وزيادة نفقات نقل المحصول.

وذلك وفقاً لما ذكرهن المبحوثات أثناء المقابلات المتعقة لهنة

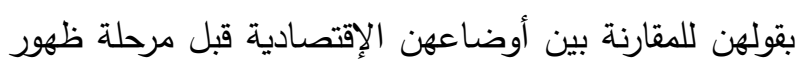

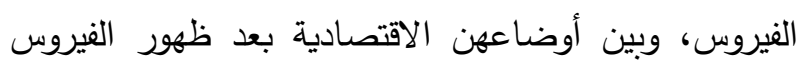

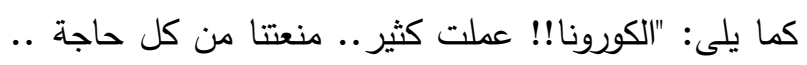
عيالنا اللى كانوا بيلقولهم يوميات وبيشتغلوا أجورين، وإحنا كنا بنربوا طيره فى الدثل بنروحوا السوق بنجييوا بيها خضار

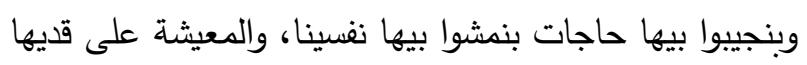

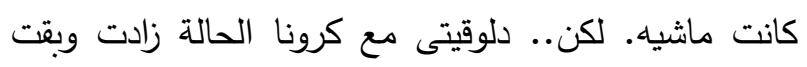

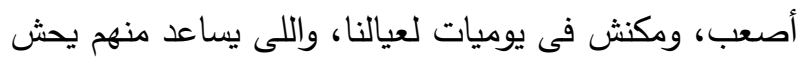

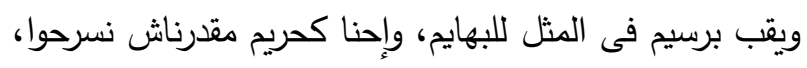

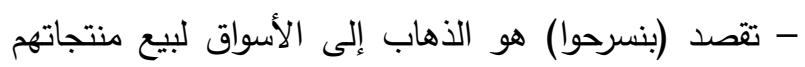
الزراعية- ولا قادرين نربوا طيره عشان الظروف، والسوق

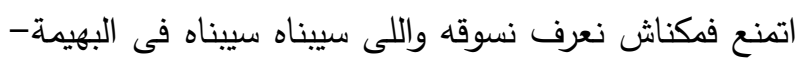

وتسويقية فى وقت الأزمة فيروس كورونا، وهى تعتبر مصدر

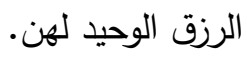
الأمر الذى يتطلب معه ضرورة اهتمام كافة الأجهزة

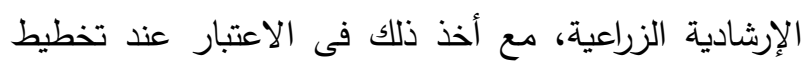

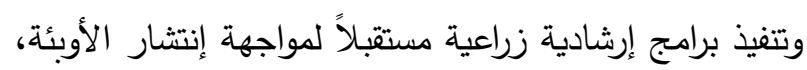

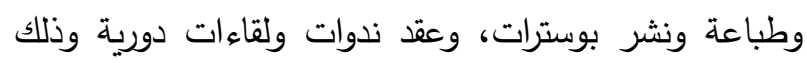
لرفع مستوى وعى المستهدفات بأساليب إدارة شئونهن الزراعية والأسرية فى آن واحد عند الأزمات وانتشار الأوبئة والأمراض، ووضع خطط مستقبلية لذلك حتى يتسنى للحائزات الزراعيات التغلب على تلك الأزمات فى زمن الأوبئة مستقبلاً.

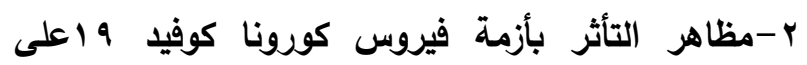
المبحوثات خلال مراحل دورة الأزمة تم التعرف على مظاهر تأثر المبحوثات بأزمة فيروس دون كورونا كوفيد 19 خلال مراحل دورة الأزمة. بسؤال

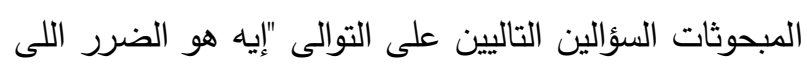

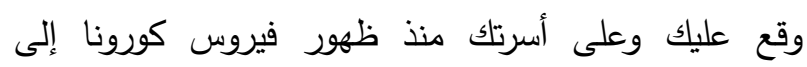

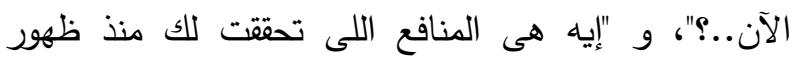

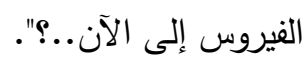
وأتضح من نتائج المقابلات تعدد وتتوع مظاهر تأثر الثرات المبحوثات بأزمة فيروس كورونا كوفيد 9 ألتى في جميع مراحل دورة الأزمة، من خلال العرض التانمة فيروش كورنا كوفيد أولا: مظاهر الضرر على المبحوثات من فيروس كورونا كوفيد 19 أتضح من نتائج المقابلات المتعقة مع المبحوثات إلى دئ وجود مجموعة من مظاهر الأضرار الناتجة عن تأثر المبحوثات بأزمة فيروس كورونا كوفيد 9 1، وقد تم تقسيم تلك الك الأضرار إلى أضرار اقتصادية، وأضرار صحية، وأضرار

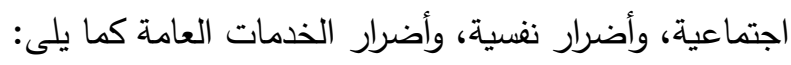


والكحول.. بس كانت مصاريف زياد والله علينا!". وذكرن أخريات أضرار مرتبطة بإنخفاض أسعار تسويق منتجاتهن، وإنخفاض المحصول، مع عدم قدرتهن على تسويق منتجاتهن بقولهن "آآه..حصلنا كتير أضرينا طبعا !! الظروف عُ إنضاقت شوية قولى شويتين فى المصاريف، والتوريد السنة دى كان أقل مجبش زى عمنول، لأني الغلة فرطتت منى لأنى مكنتش

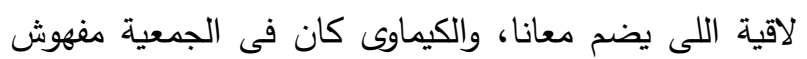
مشكلة المشكلة مش بنلاقى اللى يصرف لنا لأنه مش قاعد طول الوقت فى الجمعية بحجة أجازات كرونا، بس كنت بلاقيه، والمبيدات كنا بنجيبها من الدكان بس كانت بتكلفنا مواصلات زياده لأن المواصلات كانت واقفة."، وآخريات ذكرن "التاجر خسف بينا الأرض بعد ما الأسواق قفلوها، واللى ودى منينا المطدن، الفرق أخده فى مصاريف نقلهم.". وقد حددن المبحوثات فترات ظهور الأضرار الاقتصادية لهن بقولهن "من أول من حظروا المدارس ومنعوا العيال ولغاية دقيتى."، و"محسناش بده إلا ما تحظرنا من الدولة وللآن محظورين ومستأين من الوضع ده اللى إحنا فيه."،

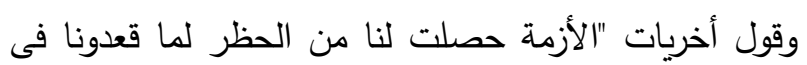
البيوت، لكن قبل ما نتحظر مكنش فى خوف ولا كنت متوقعه اللى حصل فى الحظر .. بس ربك لما يريد." ب- - 1 - (ضرار اجتماعية أوضحت نتائج المقابلات المتعقة أن الغالبية العظمى من المبحوثات قد عددن أضراراً اجتماعية ناتجة من تأثرهم بأزمة فيروس كورونا. وأن أثد فترات مظاهر تأثر المبحوثات بالأضرار الإجتماعية لأزمة فيروس كورونا هى مرحلتى تفاقم الأزمة، وانحسار الأزمة وتمثلت بثبه إجماع لإى الغالبية العظمى من المبحوثات فى تدنى لمستوى العلاقات الإجتماعية لديهن، وقد تم تصنيفها إلى تدنى فى العلاقات

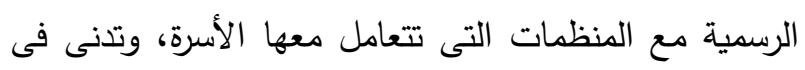
العلاقات الاجتماعية غير الرسمية لدى المبحوثات والمتمثلة فى الأهل والأصدقاء والجيران.
يعنى تم ترك اللبن فى ضرع الحيوان - والدخل أتوقف ومفيش

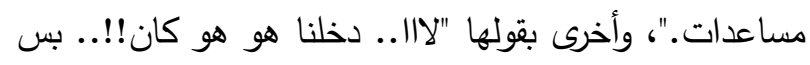

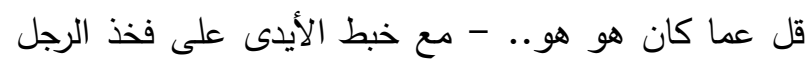
دلالة ألم وحسرة على وضعها المادى بعد ظهور فيروس هون

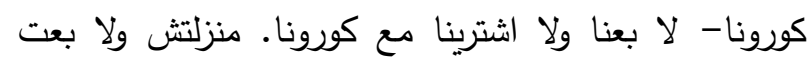

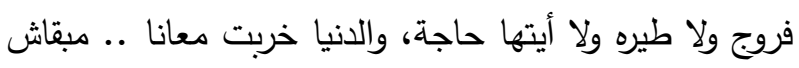
فى فلوس معانا نصرف زى الأول"، وعبرن عن انخفاض الدخل مع البطالة بقولها "ولما فرضوا الحظر علينا .. قعدونا فى البيوت وبقى مفيش شغل ولا عارفين نجيب مصاريف، ولا عارفين نصرف حاجاتتا - نصرف حاجاتتا بمعنى بيعهم للمنتجاتهم من الطيور والبيض واللبن - وولادى ضاقت عليهم لا سرحه، ولا يوميه"، وأخرى عبرت عن أضرار مرتبطة

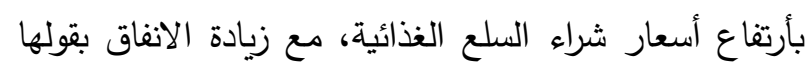

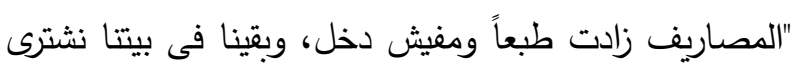
الخضار بسعر أعلى لأنه بيجى لغاية باب البيت غير ما كنا بنجيبها من السوق أرخص فى الأول.. وكمان كده كده الحال مفيش يوميات يشتغلوها العيال.. وكنا مستنين ربك يعدلها."، و"قفلة السوق ضرتنا بدل ما كنا فى السوق بنجيب كل حاجة كانت قدامى والسعر اللى يعجبنى اشترى بيه، بقيت أشترى

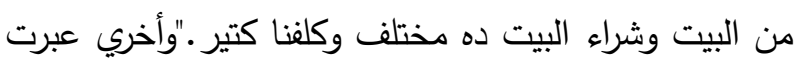
بقولهما "حسينا كل حاجة فى غلا .. وحسينا حاجاتتا مش عارفين نتصرف فيها.. ولا طيورنا، ولا أسواق، ولا خضار منعرفش نشترى .. كان فى عطلة فى كل حاجة والأشغال واقفة كلها."، بينما عبرت آخريات عن أضرار مرتبطة بأرتفاع تكاليف العلاج مع زيادة النفقات على مستلزمات طبية للوقاية من فيروس كورونا بقولهن "العلاج غلى، وكل حاجة غليت، والأكل والثرب غلى والدخل قل، وعيالنا قعدت من اشغالها، والأسواق قفلت مش بنصرف حاجاتتا فى الأسواق زى الأول." وبعضهن ذكرن "واللى زاد وغطى علينا مصاريف كرونا اللى بقى لازم تجيبى كمامات، وديتول، وصابون ومطهرات، ودى مصاريف زياده علينا وكانت غالية أول ما حظرونا، وكنا متضرين نجبوها، لكن دلوقتى مش زى الأول خفينا منها هى 
197 محمد عبد العليم على على الرميلى.: دور المزارعات الريفيات المعيلات فى إدارة أزمة جائحة فيروس كورونا (كوفيد -9 ()............

أما كوم أمبو فهو مركز بمحافظة أسوان وهو مقر لأحد

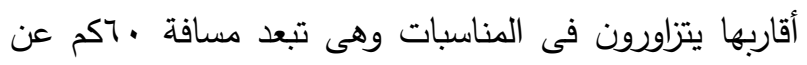

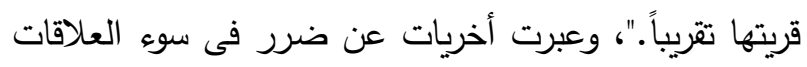

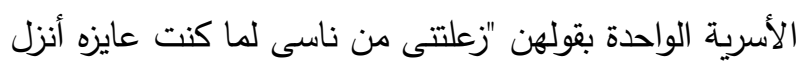

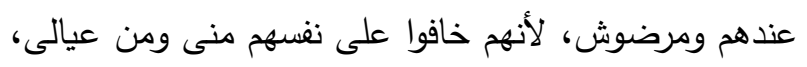

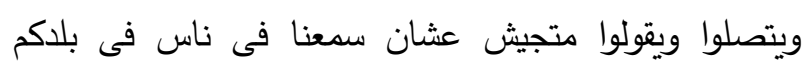
جاتلهم الإصابة ومش ناقصين حد يتصاب بسببكم."، و"خلت الأخوات يخافوا من بعض، والأخ بقى يهرب من أخته ..

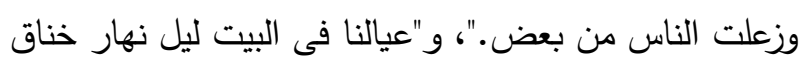
مفيش حاجة يعملوها غير التلفزيون وخناق عليه."، وعبرت أخريات عن ضرر فى سوء العلاقات داخل المنزل الواحد بقولهن "العيال طلباتهم كل يوم مبطلتش ومفيش مدارس، وده كان مخلينا فى خناقات كل يوم أنا وهما عشان عايزين مصروف للدكان، وعشان الخروجه واللعب بره، معذورين الحبسة وحشه وخوفنا عليهم مخلينا منطلعهمش بره، ومفيش حاجه بإيدينا نديها لهم، وضغط وحوف المصاريف خلى الواحده

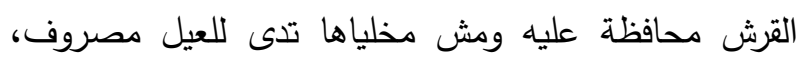
وخوف بردوا من المرض."، و "طول الحظر اللى حظرنا ده.. بقينا بس يا واد بس يا بت -فودى المثل- من كتر المناهده

$$
\text { معاهم كنامنبطلش ضرب فيهم." }
$$

وقد حددن المبحوثات فترات ظهور الأضرار الاقتصادية لهن بقولهن "كل ده حصل مع الحظر، وقعده البيت، و" لما

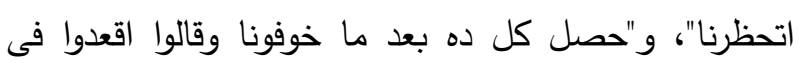
بيوتكم ومتخرجوش لناسكم"

ج-أضرار صحية

تبين من نتائج المقابلات أن الغالبية العظمى من المبحوثات قد عددن أضراراً صحية نتيجة لتأثرهم بأزمة فيروس كورونا فى قراهم، وتمثلت فى زيادة أعباء الرعاية

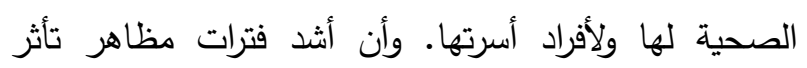

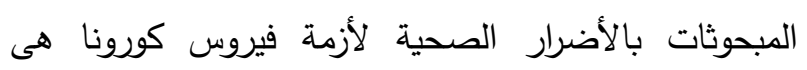
مرحلتى تفاقم الأزمة وانحسار الأزمة. وذلك نتيجة لظهور
وقد تبين أن تدنى العلاقات الاجتماعية غير الرسمية لدى الغالبية العظمى من المبحوثات فى عدم القدرة على التواصل بثكل مباشر وباستمرارية وبدون ضوابط احترازية كما كان يحدث سابقاً قبل حدوث أزمة فيروس كورونا مع الأهل والأقارب والجيران والأصدقاء، وعدم قدرتهن على تبادل الزيارات معهم فى أوقات تقديم التهنئة بالمناسبات السارة من والاهن زفاف، وخطوبة، وبقدوم مولود جديد، ولتقديم التهنئة فى

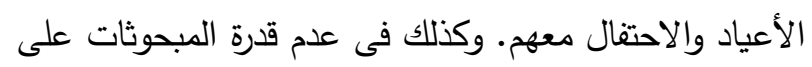
مآزرة ودعم الأهل والأقارب والجيران والأصدقاء فى حالات ولات المرض، وتثيع الجنائز، وتقديم واجب العزاء لهم. بينما

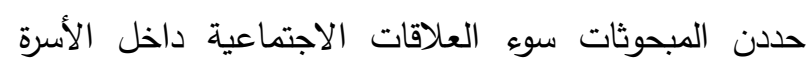
بالمنزل الواحد بزيادة المشاحنات الدائم بين الأم وأبنائها، وبين

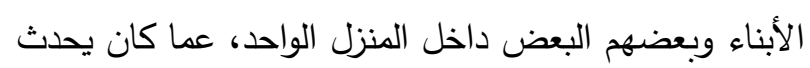
سابقاً قبل حدوث أزمة فيروس كورونا. وهذا ما رددته الغالبية العظىى من المبحوثات أثناء إجراء المقابلات المتعمقة

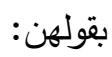
"خوفتتا من ناسنا وأهلنا - تقصد فيروس كورونا- .. عيد الله أكبر مرحتش لناس أبويا فى ادفو، ولا عيدته لأنهم قالوا فى كورونا فى ادفو فخفت أروح لهم نتصاب."، وآخريات قلن

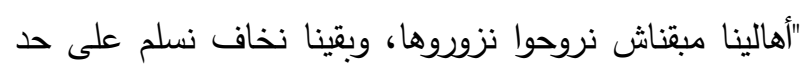
من جيرانا وأقاربنا, وبقينا مبرحوش ولا ناجى على بعضنا كتير زى الأول ومفيش فُرحات تجمع زى الأول ولا عزا

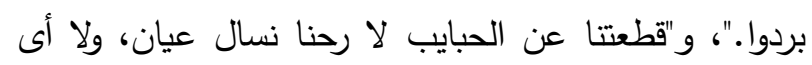

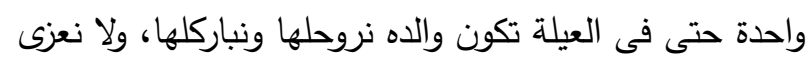

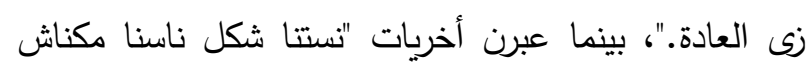
بنطلعلهم أو نزورهم لا فى عيد ولا فرح ولا عزا.. حاجة كانت

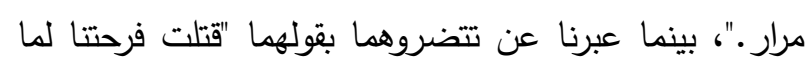

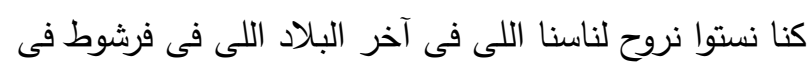
كل عيد مكناش نقدر نروح، حتى كمان فرحة روحتنا لجمعتنا

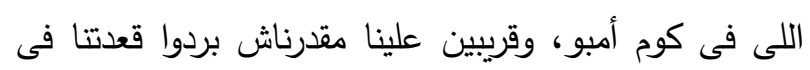
بيوتتا فى العيد. ملحوظة: فرشوط مركز بمحافظة قنا وهى ونى

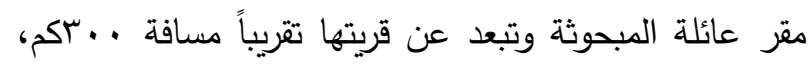


بالها ومتعرضهمش لحد، وغذوهم كويس، وكمان الناس الكبيرة فى السن، بقيت مش ملاحقة... لا على خدمة كبير ولا

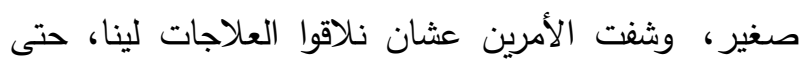
قطرة العين مكناش لاقينها.. كل ما نسألوا يقولوا كورونا.. طيب أيه علاقة كورونا بقطرة العين..؟!!". بينما بينت نتائج المقابلات الدتعقة أيضاً أن عدد قليل

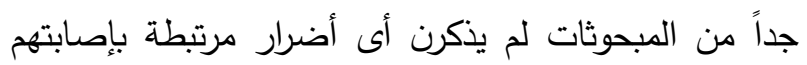

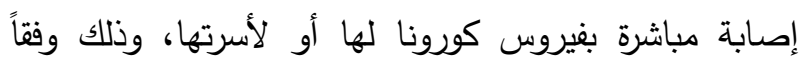
القولهن "لاء مفيش ضرر حصللى على صحتى أنا أو عيالى

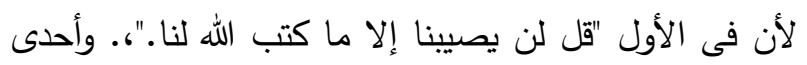
المبحوثات لم تصدق على وجود إصابات فى القرية بثكل نهائى لقولها، "لاء مفيش إصابة حصلت فى البلد بكورونا.. ومفيش خوف خالص منه لأن القرية هنا خفيفة والناس قليلة والاحتكاك كمان قليل."، وقد أكدت نتائج المقابلات أيضاً أن كل الأضرار الناتجة

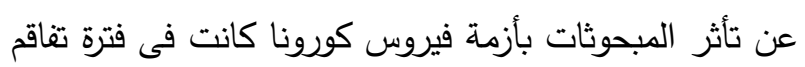

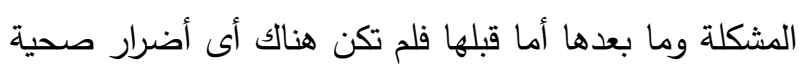

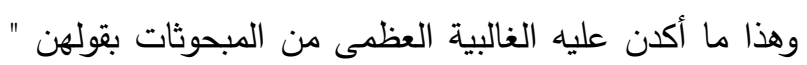

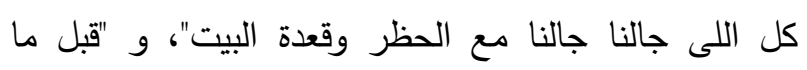

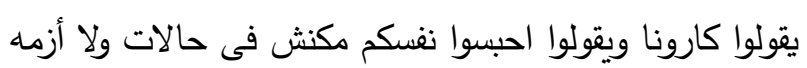
علاج لكن بعدها تعبنا كلنا".

$$
\text { د- أضرار نفسية }
$$

أفادت نتائج تحليل الدقابلات المتعقة أن الغالبية

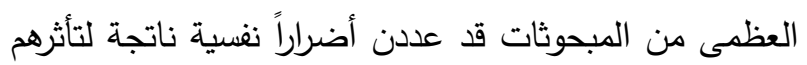

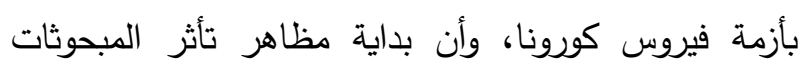
بالأضرار النفسية لأزمة فيروس كورونا كانت في الأنس المراحل

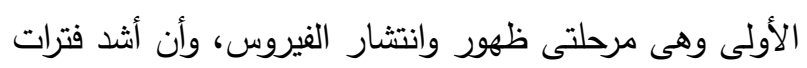
الأضرار النفسية كانت فى مرحلتى تفاقم الأزمة وانحسار

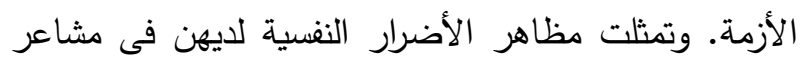

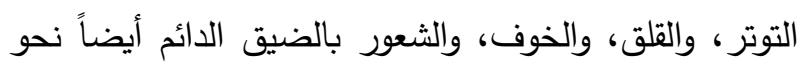

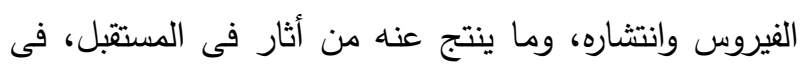

حالات اشتباه بأعراض الإصابة بفيروس كورنا لاى بعض

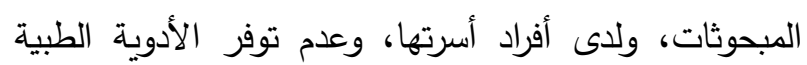

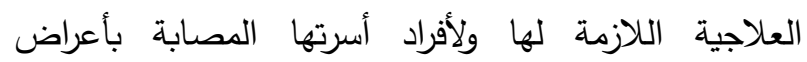

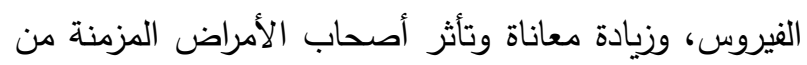
أفراد أسرتها بأمراضهم فى فترات أزمة كورونا عن فترات قبل

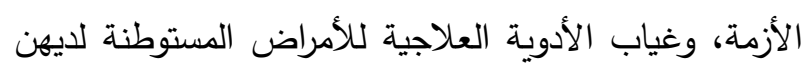
من أمراض الضغط والسكر وأدوية السيدات الحوامل والأطفال

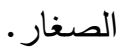
وهذا ما أبرزته نتائج المقابلات المتعقة مع المبحوثات بقولهن: "الحريم تعبت، والمره الحامل بردو تعبت وتعبتتا معاها، وكنا مش لاقين علاجات ليها وخفنا تتصاب وعزلناها عن الناس لتتصاب.. وولادنا تعبوا وجاتلهم السخانة وقالوا أعراض الكورونا لكن الدكتورة ريم قالت مش كورونا دى سخانه عادية."، بينما ردت أحدى الدبحوثات فى وصفها كنا كورنا لضرر المرض بقولها "مش بس إحنا جالنا المرض. الطيا الطير جاتله المرض، ومالنا جاله المرض، وكل الدنيا جاتلها

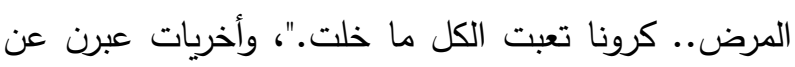

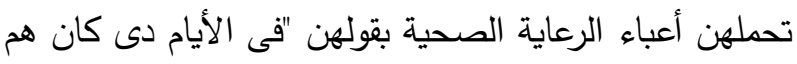

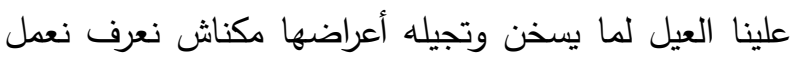

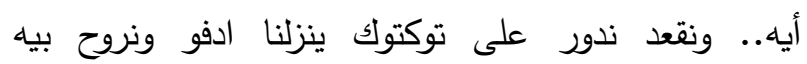

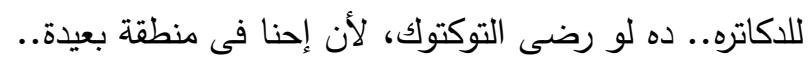
وده عبء كمان علينا، غير البنت الحامل مش ببقى عارفة التافي أعمل معاها أيه بينها وبين أخواتها وعيالها هم كان كبير التهان علينا." وبعضهن عبرن عن زيادة معاناة وتأثر أصحاب الهاب الهاب الأمراض المزمنة بقولن "كان لو حد تعب فينا يبقى مصيبه مش تعب بكورنا ..لاء.. أى تعب تانى اللى عندها الضغط،

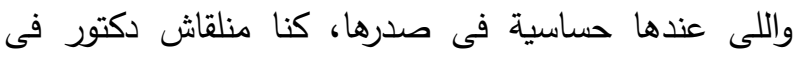
الوحدة، ولو نزلنا أى مستثفى تانى يقولونا عندنا عزل روحوا مستثفى الجامعة فى أسوان ودى بعيده خالص علينا". بينما ا عبرت أخريات تضررهن بقولهن "ثيلونا الهم كل فئل

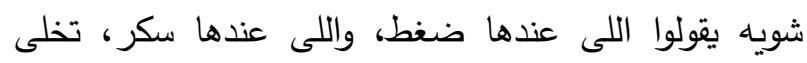


199 محمد عبد العليم على على الرميلى.: دور المزارعات الريفيات المعيلات فى إدارة أزمة جائحة فيروس كورونا (كوفيد -9 (1)..........

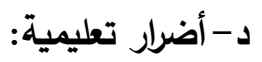

أوضحت نتائج تحليل المقابلات المتعقة أن عدد قليل

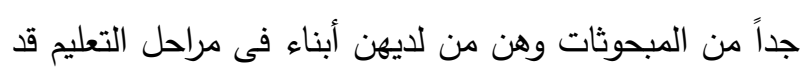

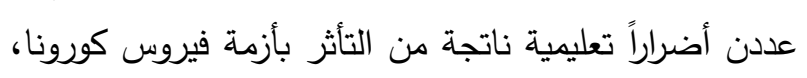

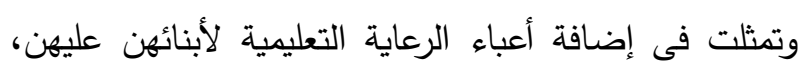

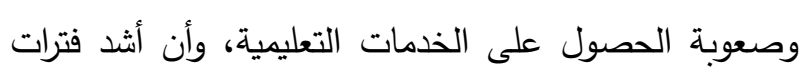

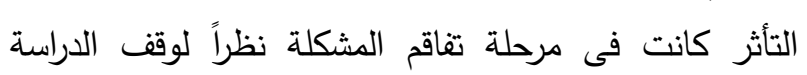
وغلق الددارس أثناء فترة الحظر، وأن عدم تكملة أبنائهن

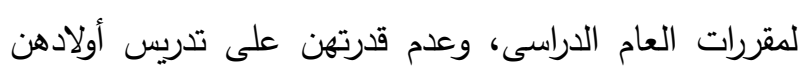

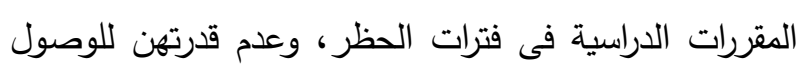

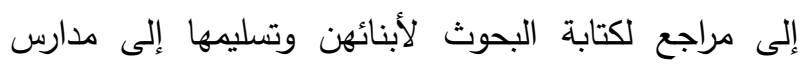

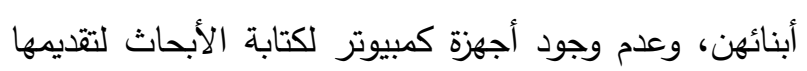
إلى الدارس كمتطلب لتصعيدهن للمستوى التعليمى الأعلى.

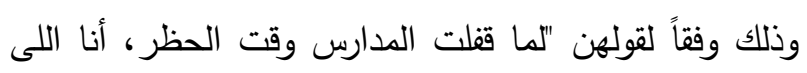

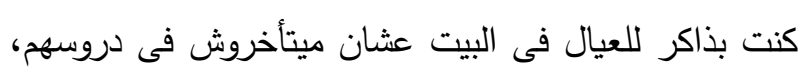

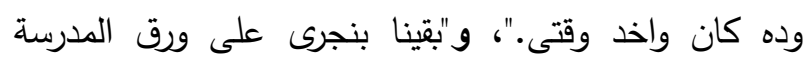

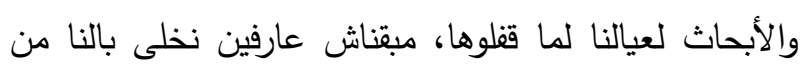

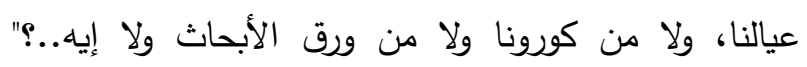

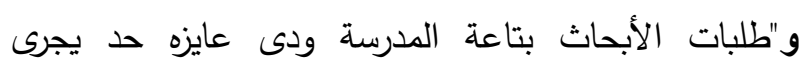

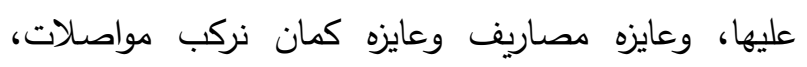
وعايزه نت كمان وإحنا التليفون مش عيلقط شبكة عشان نلقط نركان

$$
\text { نت. وعايزه نت }
$$

و - سوء الخدمات العامة أبرزت نتائج تحليل المقابلات المتعمقة أن أقلية من ألماته المبحوثات قد عددن أضراراً مرتبطة بسوء الخدمات العامة

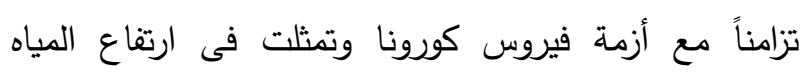

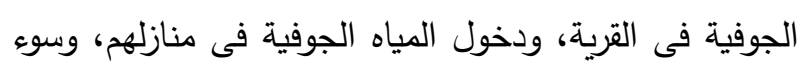

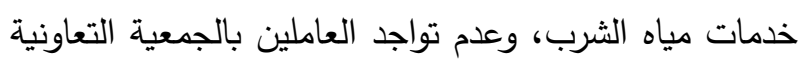

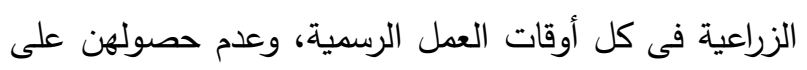

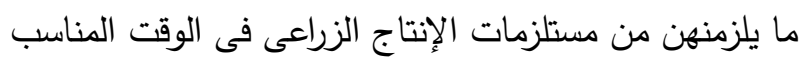
للعمليات الزراعية، وعدم تواجد الأطباء، وتوفر الخدمات الزتات النيات
خلال فترتى ظهور وانتثار الفيروس. ومشاعر القلق والخوف

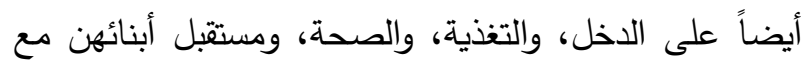

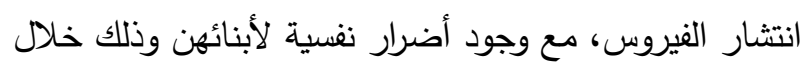

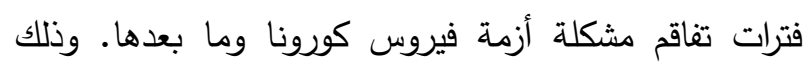

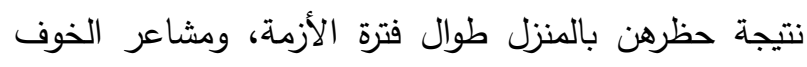

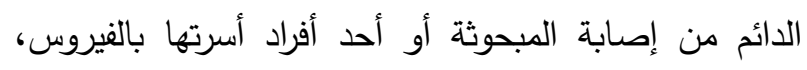

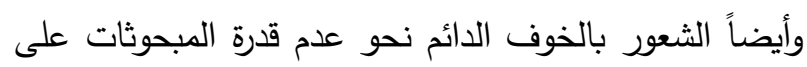

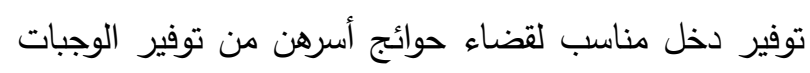

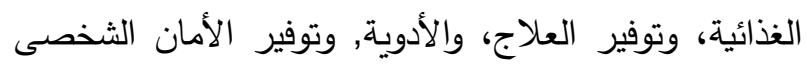
لها ولأفراد أسرتها، ومثاعر الخوف من وفاة أحدا أفراد أسرتها

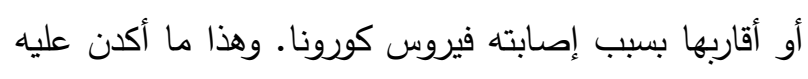

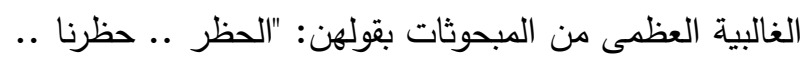
خلانا نخاف من كل حاجة"، و "كان فى ضيق ولئ والنفسية تعبانه

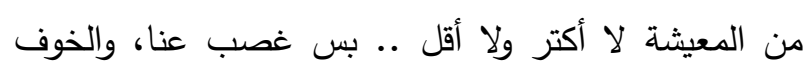

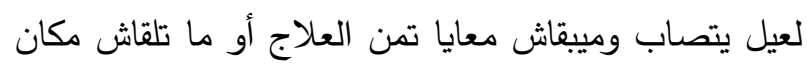

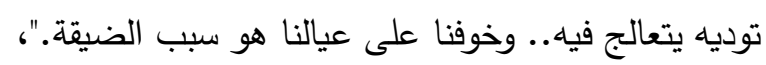
بينما أخروين عبرنا عن تتضروهما بقولهما "ايوه اضرينا

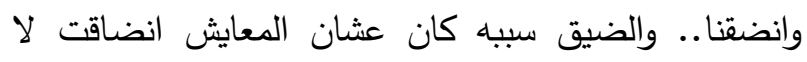

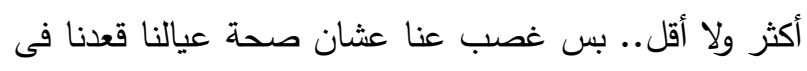

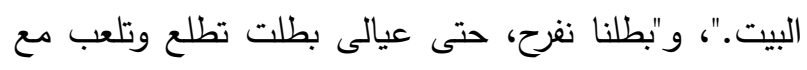

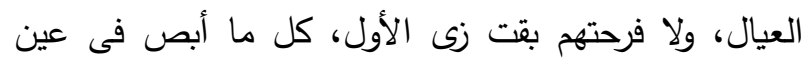

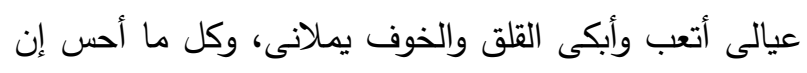

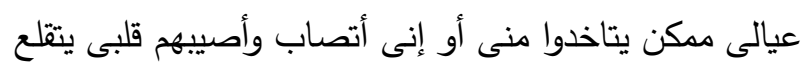

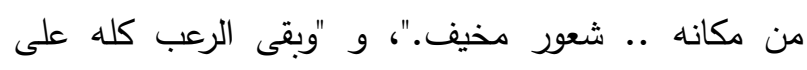

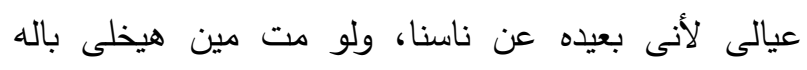

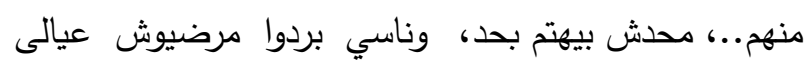

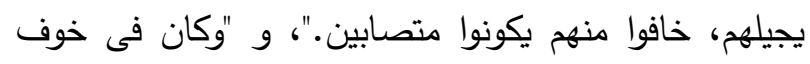

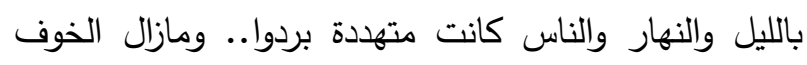

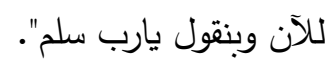


لدورة أزمة كورونا. وأن الأضرار الاقتصادية على المبحوثات كانت أكثر تتوعاً وضرراً عن باقى الأضرار الأخرى المذكورة.

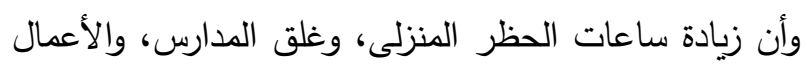
وتواجد فترات أطول لأفراد الأسرة بالكنزل دون أى أعمال العال العال العال تذكر أدت لتعاظم الأضرار الاقتصادية لاى المبحوثات خلال

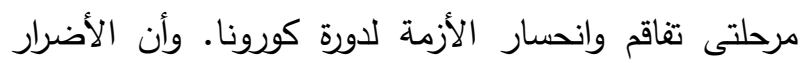
الصحية لم تتضمن تعرض المبحوثات أو أحد أفراد اسرتها

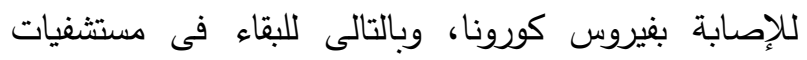
العزل، وأن عناء المبحوثات فى الوصول للخدمات الطبية، والحصول على العلاجات الدوائية سواء للحماية من فيروس التردي كورونا أو للتداوى من أمراض أخرى، وتحملهن لأعباء

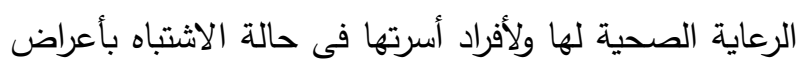

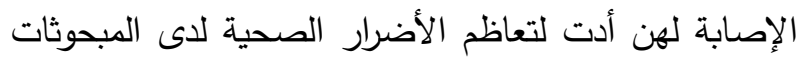
خلال مرحلتى تفاقم وانحسار الأزمة لدورة كورونا.

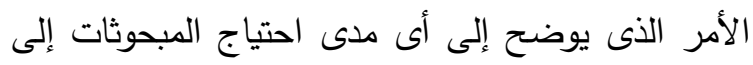

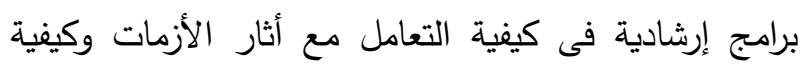

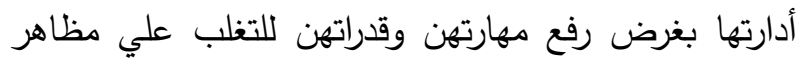
الضرر مع تكثيف المبادرات التعليمية الإرشادية لنشر معارف

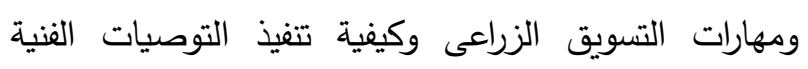
الإرشادية الخاصة بأساليب التسويق الجيد وقت الأزمات.

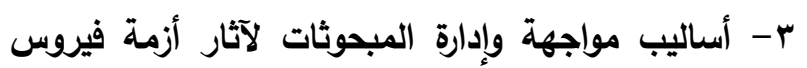
كورونا كوفيد 19 خلال مراحل إدارة الأزمة أمكن التعرف على أساليب المبحوثات فى مواجة أثار أزمة فيروس كورونا كوفيد 9 وإداراتهم لها من خلال سؤال المبحوثات السؤال التالى (إزاى اتعاملتى مع أزمة كورنا...؟؟).

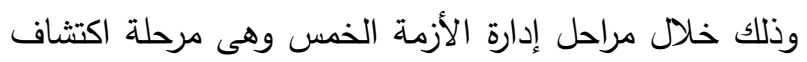

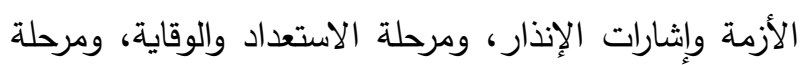

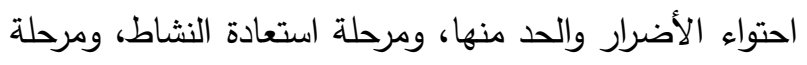

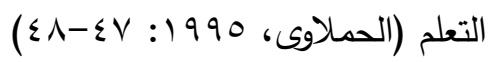

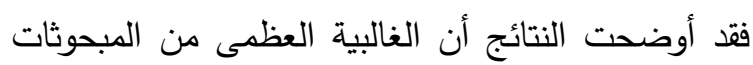

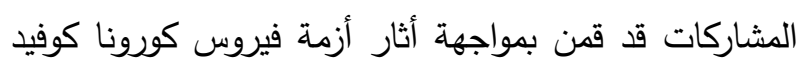

الطبية بالوحدة الصحية بالقرية، والاكتفاء بخذمات الزائرات الصحيات فقط، وعدم وجود منظمات تقدم لهم الدعم الفنى

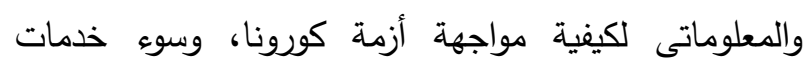
الاتصال والإنترنت بالقرية، وعدم توفر المواصلات فى القية أقرية تزامناً مع أزمة فيروس كورونا،

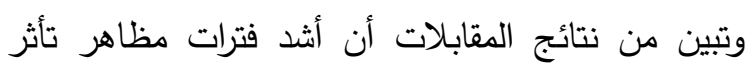
المبحوثات بسوء الخدمات العامة تأثراً بأزمة فيروس كورونا

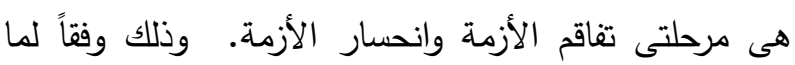

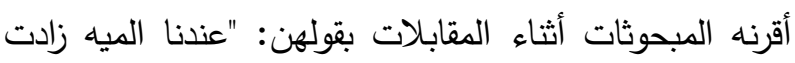
وبقت جوه خشم البيت ولا لقيناش اللى ينجدنا كله فى كورونا

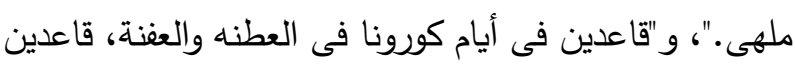
فى عطانة المية، وغرق بره وجوه، وربنا يعافينا.، و وإحنا وقينا نفسنا بنفنا فى العطنه اللى إحنا فيها.. عطنة والميه إحنا

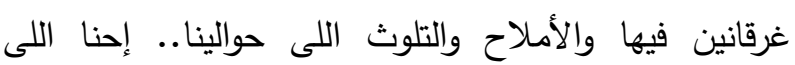
بقاومه وربنا ساتر علينا". و ومفيش دكتور فى الوحدة، بنزل له الدكتور نجيبه من تحت - مركز ادفو- وبتوع الجمعية كل ما نروح منلقاش يقولوا إجازة كورونا عشان حصة الكيماوى." ثانياً: مظاهر النفع على المبحوثات من أزمة فيروس كورونا

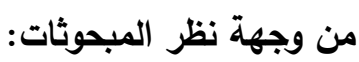

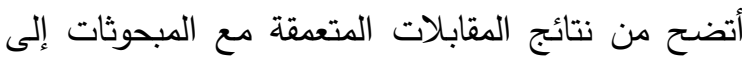

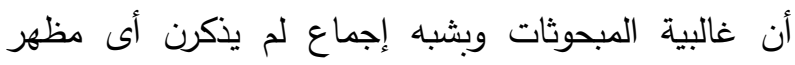

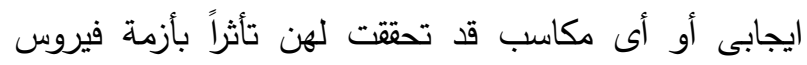
كورونا كوفيد 19 خلال مراحل دورة الأزمة على المبحوثات. وذلك وفقاً لما ذكرنه المبحوثات بقولهن: "محسناش بأى ميزه

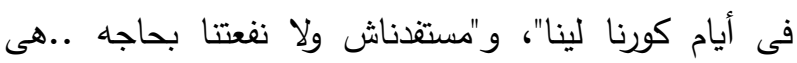
فادت حد عشان تثيدنى أنا"، و"مفيش حاجه حلوة عملتها

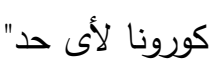
ومن العرض السابق يتضح أن مظاهر تأثر المبحوثات بأزمة فيروس كورونا تمثلت فى جانب واحد فقط وهو مظاهر الضرر دون وجود أى مظاهر للنفع، وأن أكثر المراحل تأثراً بمظاهر الضرر هى مرحلتى تفاقم الأزمة وانحسار الأزمة الفران 
201 محمد عبد العليم على على الرميلى.: دور المزارعات الريفيات المعيلات فى إدارة أزمة جائحة فيروس كورونا (كوفيد -9 (1)......

ب. مرحلة الاستعداد والوقاية: وهى المرحلة التى يتم فيها الاستعداد والوقاية فى حالة حدوث الأزمة، فقد أوضحت

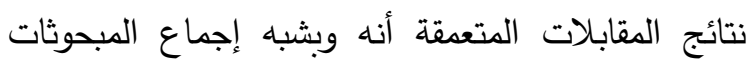

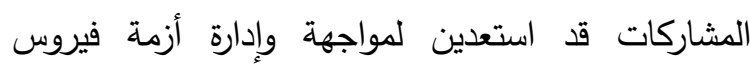

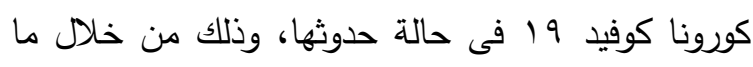

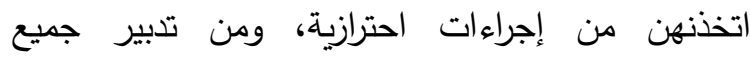

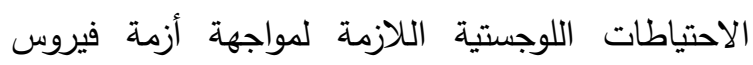

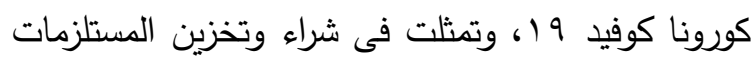

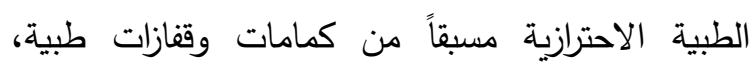
وأدوات التتظيف والتطهير والتعقيم من منظفات صناعية

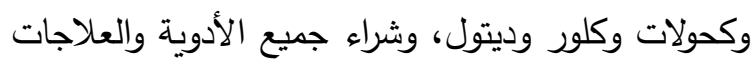
الطبية الموصى بها من أدوية خافضة للحرارة وأدوية نزلات البرد، والفيتامينات. وقد عبرن عنه المبحوثات بعبارات تدل على ذلك عند طرح السؤال التالى عليهن: (بعد ما سمعتى وعرفتى معلومات عن كورونا وأضرارها

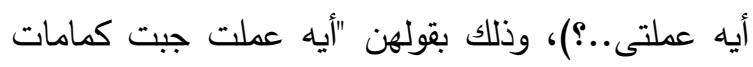
وجبت ديتول وجبت البخاخه اللى هى الكحول ..عثان بـان

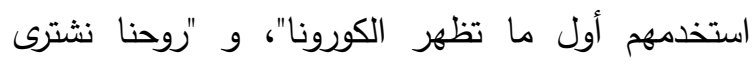
الإسعافات الأولية زى البكرات - لفة المناديل الورق-

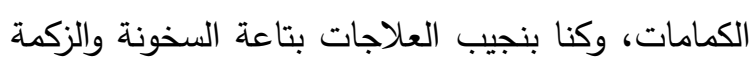

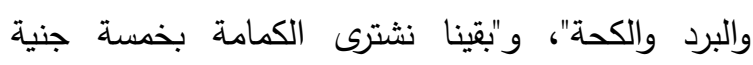
ونشتريها بالدستة، وبقينا نجيب الديتول ومطهرات لونيات

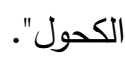

ج. مرحلة احتواء الأضرار والحد منها: وهى مرحلة المواجهة

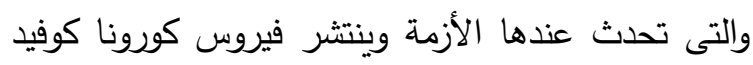

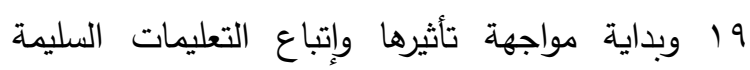
للمواجهة. وتم التعرف عليها من خلال سؤال المبحوثات

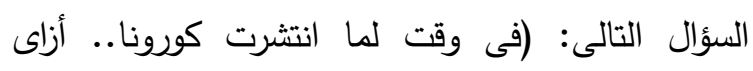

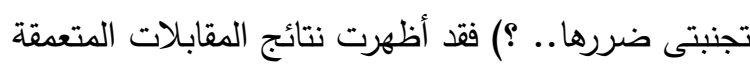

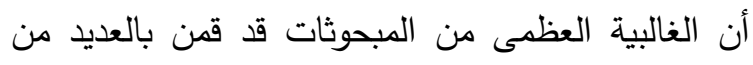

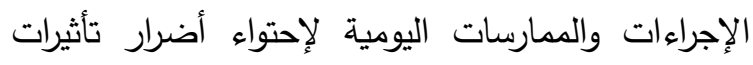

19 وإداراتهم لها من خلال عدة خطوات لتلافى الأزمة

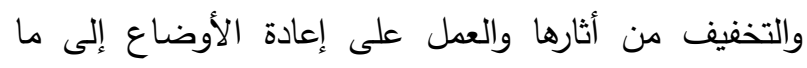
كانت عليه قبل حدوث الأزمة كالآتى: أ. مرحلة اكتثاف الأزمة وإثارات الإنار: أبرزت الإندات النتائج

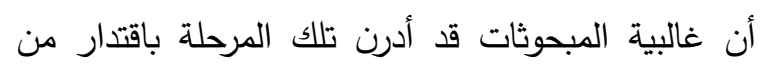
خلال مجموعة الممارسات التى تم تتفيذها من قبلهن وهى: البحث الدائم فى وسائل الأعلام لجمع البيانات والمعلومات عن فيروس كورونا كوفيد 9 1، وعن مسبباته وخطورته، والتى نتج عنها رفع وعيهم بفيروس كورونا كوفيد 9 1، ومسبباته، وأيضاً قدرتهن على ولى تحديد أضراره ومكمن الخطر منه. وقد تم التحقق من ذلك بطرح السؤال

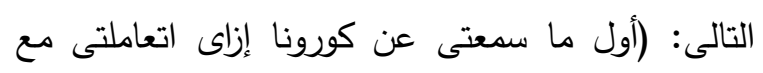

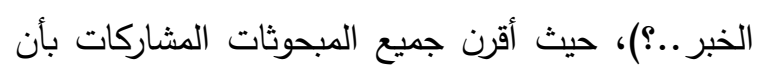

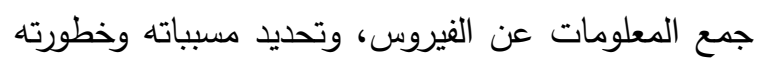

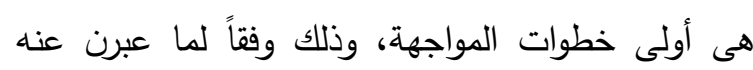
المجحوثات بعبارات تدل على ذلى ذلك مثل قولهم: "كنات

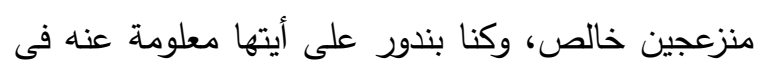

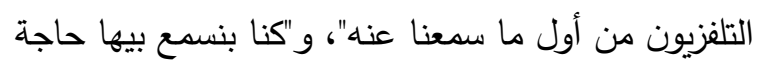
جاية من بعيد بعيد!!.. من عند ناس بلاد بره، وبقينا

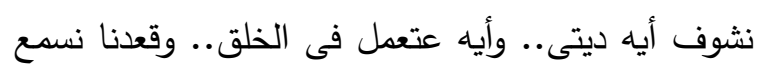

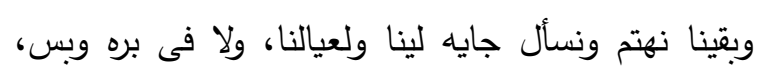

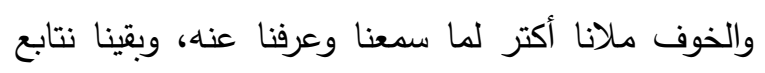

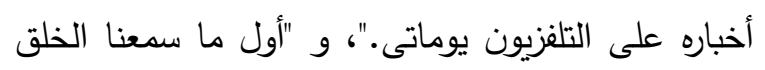
كلها خافت وأنا منهم خفت قوى على على عيالى وحالنا ومالنا

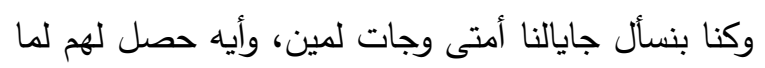

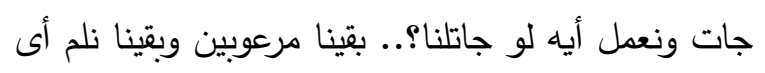

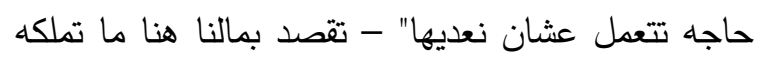

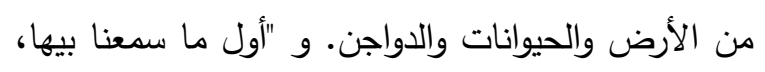

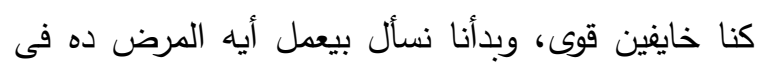

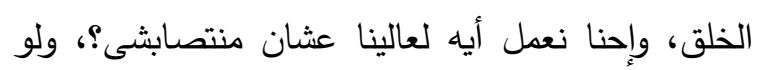

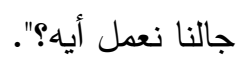


بس لأنى ساكنة على الزرع."، و "طول فترة كورونا تقصد فترة الحظر - منزلتش ولا رحت السوق كان من لن بيتى أأكل عيالى وعربية الخضار تاجى لحد باب البيت وأشترى منها اللى عاوزاه"، تعبيراً عن إجراء الالتزام بساعات الحظر المعلنة من قبل الدولة ومنها البقاء بالمنزل، وعدم الذهاب للأسواق وقت الغلق، بينما عبرن أخربات بتطبيق الاجراءات الاحترازية الثخصية بقولهن "عملت أليه - صمت مع لحظه تفكير وتذكر - حافظت على نفسى وعلى عيالى.. لبست ولبستهم الكمامة.. ولو ركبت عربية ألبس كمامة، بطلنا نسلم على حد ولو هسلم على حد ألبس الجونتى."، وعبرت أخريات بعدم المشاركة فى التجمعات والمناسبات المختلفة وعدم إجراء الزيارات

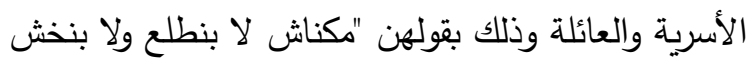

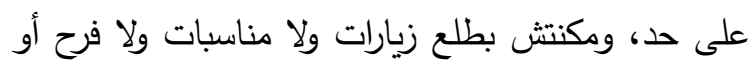
ولادة لأى مره يعنى ولا موت طلعنا ليها السنة دى."، و"مبقتش أطلع أنا وعيالى، ومنعت حتى الزيارات لأهلى.. مثلاً أنا أهلى من مصر -تقصد القاهرة - مبقتش أروح

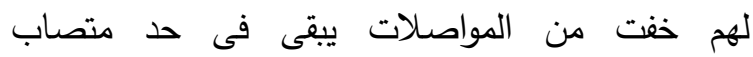
ويعدينا."، ومن قيامهن بتقديم الوجبات والأغذية الصحية والمقاومة للفيروس ورافعة للمناعة وذلك لقولهن "كنت ودين أوكل عيالى البصل والتوم والجرجير والثطة، ودوول كانوا بياجوا على التلفزيون لما كنت باسمع عن كورونا، وكانوا بيقولوا كترو من الحاجات دى فكنت بكتر منها."، وقد عبر بعضهن عن احتواءهن للأضرار بالتوجه للطبيب

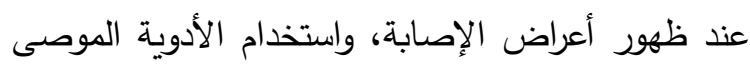
بها مع عزل كل من يتعرض لمظاهر الإصابة وذلك الإنك بقولهن: "أى حاجة تحصل للعيل بنخاف عليه ونرمح عليه للدكتور ، واللى مسخن شوية نعزله، وكنا بنعزل نفسنا لهاب

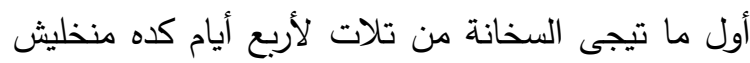

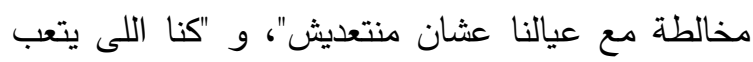
أو يسخن أو يجيلة برد نجيبلة برشام النوفالجين والفاسلين

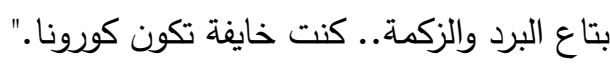

أزمة فيروس كورونا كوفيد 9 1، والحد من أضرارها فى

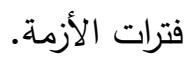

وقد تم تقسيم الإجراءات والممارسات المستخدمة من قبل المبحوثات فى احتواء الضرر والحد منها وفقاً لنوع الضرر

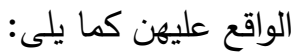

1- احتواء الأضرار الصحية وإلحد منها: وقد تمثلت فى الالتزام بتتفيذ الإجراءات والممارسات الاحترازية التى اتخذتها الدولة لها ولأفراد أسرتها من الالتزام بساعات الحظر المعلنة من قبل الدولة ومنها البقاء بالمنزل، وعدم الخروج من المنزل إلا للضرورة القصوى، وعدم الذهاب لأسواق القرى، وعدم المشاركة فى تجمعات والمناسبات

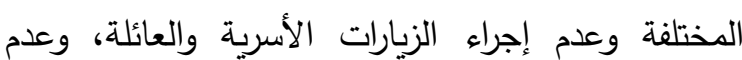
استخدام وسائل المواصلات العامة إلا للضرورة مع أخذ الإجراءات الاحترازية، مع المواظبة على لبس الكمامة عند الخروج من المنزل. وعدم المصافحة بالأيدى والتقبيل للآخرين، والمواظبة على النظافة الشخصية مع استخدام المنظفات والمطهرات، وغسل الدائم للأيدى والملابس والأغراض الثخصية مع تعقيمها باستمرار، وتقديم الوجبات والأغذية الصحية والمقاومة للفيروس ورافعة للمناعة، واستخدام أدوية خافضة للحرارة وأدوية الأنفلونزا الموسمية عند حدوث ارتفاع لدرجة حرارة الجسم أو عند

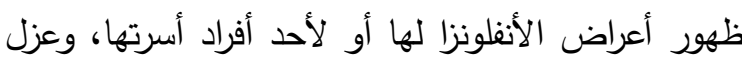
كل من يتعرض لمظاهر الإصابة بفيروس كورونا كوفيد

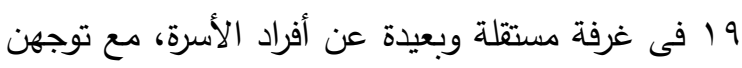

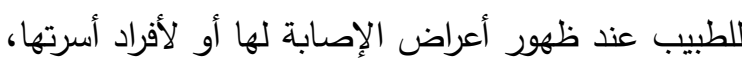
وذلك وفقاً لما عبرن عنه المبحوثات أثناء إجراء المقابلات بقولهن: "التزمنا بالإجراءات زى اللى بنسمعها فى في التلفزيون ما بنطلعش كتير"، و"مبقناش نروح الأسواق، والعيال مخلياهم ميخرجوش ولا يسرحوا عشان البرد

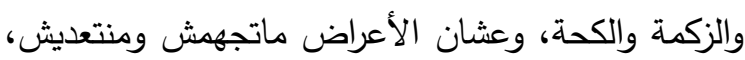
وكنا من زرعنا لبيتنا لا نروح ولا نرجع، وكنا بنروح الزرع 
203محمد عبد العليم على على الرميلى.: دور المزارعات الريفيات المعيلات فى إدارة أزمة جائحة فيروس كورونا (كوفيد -9 ( )..........

له. مكنش في، بقينا ناخدهم لينا ونغليها كويس ونأكل كويس ونتقوى بيها عشان خاطر الزكام والسخانة لأننا كنا بنخاف."، وأكدن أخرويات على ذلك بقولهمن " الحاجة اللى كنا بنجيب منها r كيلو من السوق بقينا نجيب كيلوا واحد بس من قدام البيت."، و"بقينا نبيع من البيت الحاجه

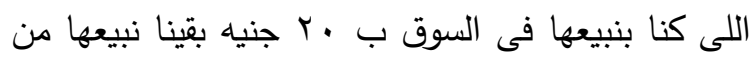
البيت ب 10 جنية، وخسارة قرببة ولا مكسب بعيد."، و عبرت أخريات عن الاعتماد على الذات فى تقيل نفقات العمالة الزراعية بقولهن "كنا إحنا اللى شغالين فى الى لئى أرضنا."، و "مكنش معانا فلوس عشان نجيب اجريه، فكنا

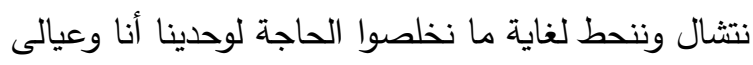
ومعندناش إمكانيات إحنا نجيب حدد يساعدنا فى الزرع بفلوس"

وتبين أيضاً أن من نتائج المقابلات إلى وجود عدد قليل جداً من المبحوثات لم يقدرن على إدارة تأثيرات أزمة فيروس كورونا كوفيد 9 (، وذلك لعدم قدرتهن على إستخدام ممارسات

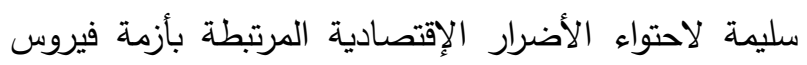
كورونا. وذلك وفقاً لما عبرن عنه المبحوثات بقولهن: "معرفناش نعمل أيه فى حاجاتتا ولا صرفناها .. كنا بنكبها..

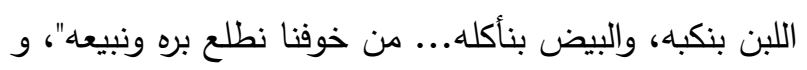

"والله كنا مخلينها فى البيت لحد ما أكلناها فى أيام الزنقة." ץ- احتواء الأضرار الاجتماعية والحد منها: فقد بينت نتائج المقابلات المتعمقة عدم قدرة غالبية المبحوثات على إدارة أزمة فيروس كورونا كوفيد 9 اوأثارها، وذلك من خلال الممارسات المستخدمة لاحتواء الأضرار الاجتماعية المرتبطة بعدم القدرة على التواصل بشكل مباشر الاصر وباستمرار مع الأهل والأقارب والجيران من خلال استبدال

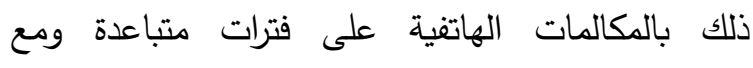
المناسبات، وذلك لضعف شبكات المحمول بالقرية، وعدم وجود هواتف أرضية، والتواصل عن بعد مع الجيران على ودلى فترات وبضوابط احترازية، وفيما يتعلق باحتواء المشاكل r- احتواء الأضرار الاقتصادية والحد منها: فقد بينت نتائج المقابلات المتعمقة أن غالبية المبحوثات لديهن القدرة على إدارة أزمة فيروس كورونا كوفيد 9 اوتأثيراتها وذلك الك

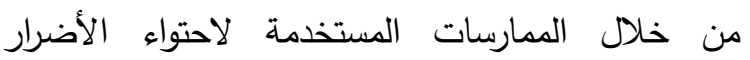
الإقتصادية المرتبطة بانخفاض الدخل للمبحوثات، وذلك بتوفير النفقات، والاعتماد على المخزون من السلع والأموال لايهن، وتسويق السلع والمنتجات من منزلهن وبالمقابل المادى لها يتم شراء الخضروات من الباعة المتجولين أمام منزلهن، والبيع بأسعار أقل من الأسعار المتداولة فى السوق لتصريف ما لديها من منتجات لتوفير سيوله ماليه، وتوفير فى الكميات المستهلكة، والكميات المشتراه، ومحاولة تحقيق الاكتقاء الذاتى من خلال الاعتماد على مواردهن الذاتية، وذلك بالاستعانة بالمنتجات الغذائية غير المباعة لديهن واستخدامها كبديل للسلع التى تشترى من الأسواق مثل الطيور المنزلية غير

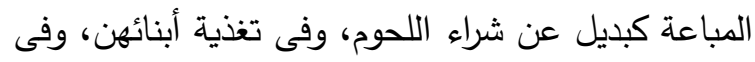
نفس الوقت استخدامها كوسيلة لزيادة المناعة لدى أفراد

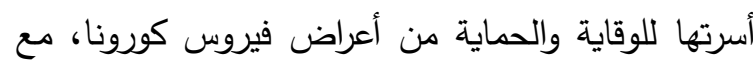
التقليل نفس الوقت من الكميات التى تصنعها من منتجات

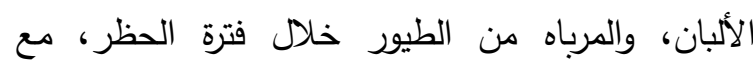

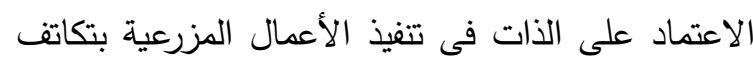
أبناء الأسرة الواحدة فى القيام بالأعمال المزرعية لتوفير أجر العمالة، وتقليل نفقات العمالة. وذلك وفقاً لما عبرن عنه المبحوثات بقولهن: "وفرنا فى مصاريف الأكل كنا بنأكل من بيتنا البصل والتوم والخضار ، ونطبخ من بيتنا مكناش بنجيب حاجة من بره"، وعبرت أخريات عن تسويق السلع والمنتجات من منزلهن والشراء من الباعة المتجولين أمام منزلهن بقولهن "دلوقتى بقينا فى بيتنا نبيع الطير الكل عارفنى وبيعدى عليا يأخد، وبتمنه ناخد الخضار من العربية اللى بتعدى قدام البيت وماشيه والحمد لله"، و "والطير اللى بطلنا نبيعه أكلناه لعيالنا، وشويه البيض والجبنه إذا حد سأل فى البيت تمام نبيع 
0- احتواء الأضرار النفسية والحد منها: فقد بينت نتائج المقابلات المتعمقة عدم قدرة غالبية المبحوثات على إدارة

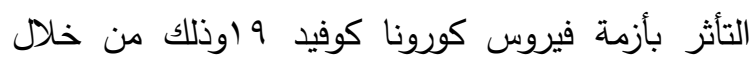

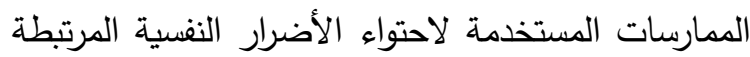
بمشاعر الخوف والرعب والقلق خلال أزمة فيروس كورونا كوفيد 9 ابخطوات مدروسة وعلمية، ولكن أدرنها بشكل دينى من إقامة الصلاة والدعاء فى جميع الأوقات مع الهع

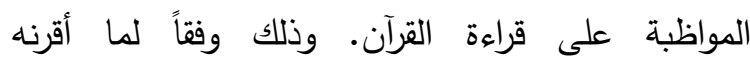
المبحوثات بقولهن: "والخوف والرعب اللى جوانا نعالجه إزاى ده كمان.. إحنا اتولدنا به وعايش لسه معانا.. بس لبس ربك الحافظ"، و "ربنا عنده العفو، واللى لله نصيب فى لهى حاجه هتجيله، ممعناش حاجة غير الدعوات وإن ربنا يحفظنا ويحمى عيالنا"، و "مين يقدر يوقف الخوف اللى كان جوانا وقتها؟، إلا ربك قادر على كل شىء."، و "بقينا نصلى وندعى من الخوف، وكل صلاه ندعى ونقرا قران على طول.. مبطلناش قرايه".

7- احتواء الأضرار سوء الخدمات العامة والحد منها: فقد بينت نتائج المقابلات المتعمقة وبشبه إجماع عدم قدرة غالبية المبحوثات على إدارة التأثر بأزمة فيروس كورونا كوفيد 9 اوذلك فيما يتعلق بسوء الخدمات العامة الناتجة عن تأثيرات فيروس كورونا كوفيد 9 أ. وذلك لقولهن: "نعملوا أيه فى الميه اللى دخلت البيوت، فى المثل رحنا وشكينا لكن مفيش حل، والموظفين إجازات كورونا"، و "وهو حد سأل فى حد شكينا وبكينا لكن ربك كبير

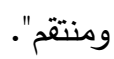

د. مرحلة استعادة النشاط: وتسمى مرحلة تخطى الأزمة

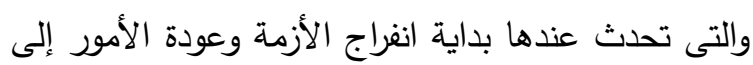
طبيعتها بدرجات متتالية. فقد أظهرت نتائج المقابلات المتعمقة أن الغالبية العظمى من المبحوثات قد قمن لئن بالممارسات اليومية للعودة إلى أنشطتهن اليومية، واحتواء

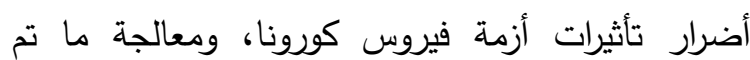

الاجتماعية داخل الأسرة الواحدة فكانت تتم بطرق شبه تقليدية كالمعتاد بين أفراد الأسرة الواحدة وبدون تخطيط أو الو الودان ترتيب يذكر من المبحوثات. وذلك وفقاً لما ذكرهن بقولهن: "أى حد أقابله من جيرانى بقيت أنادى عليها وأسلم من بعيد لبعيد ونهزر ونضحك ونقول سلام كورونا"، و "كل ما بقينا نسمع عن عزا نتصل ونعزى بالتليفون، واللى تخلفلها عيل نكلمها بالتليفون بس الناس مش قابله بس نعملوا أيه، قضى ربك"، و و "الثبكة مش بله مخلينا نعرف نتكلم على طول، فين وفين لما تلقط ونتكلم نطمن على ناسنا".

ع- احتواء الأضرار التعليمية والحد منها: فقد بينت نتائج المقابلات المتعمقة عدم قدرة عدد قليل جداً من الهن المبحوثات ممن لديهن أبناء فى التعليم على إدارة التأثر

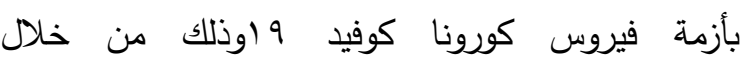
الممارسات المستخدمة لاحتواء الأضرار التعليمية والناتجة عن تأثيرات أزمة فيروس كورونا كوفيد 9 أعلى أبنائهن فى مراحل التعليم المختلفة، بسبب انخفاض مستوى التعليم لديهن، وعدم قدرتهن على إستخدام تكنولوجيا التعلم الحديثة، وعدم وجود مكتبات علمية ومراجع بالقرية، وضعف شبكات الاتصال واستخدام الانترنت، وقد عالجن وجن هذه الأزمة باللجو إلى غيرهن لإتمام الأبحاث المطلوبة لأبنائهن لتجاوز متطلبات التعليم. وذلك وفقاً لما عبرن عنه المبحوثات بقولهن: "لما قفلوا المدارس أنا كنت بذاكر ولهر للبت فى البيت، لغاية ما قالوا أبحاث وقفت ومعرفتش بعت لكن خليت سيبر (مكتب كمبيوتر) وعملنا الأبحاث ونجحت الحمد الله"، و "مدارس العيال عدت قالوا أبحاث وإحنا ملناش فى التعليم ولا كمبيوتر ولا نت، خلينا واحد عملهح

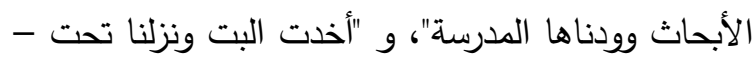
تقصد مركز ادفو - وبتوع الكمبيوتر أدونا الأبحاث

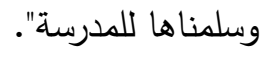


205 محمد عبد العليم على على الرميلى.: دور المزارعات الريفيات المعيلات فى إدارة أزمة جائحة فيروس كورونا (كوفيد -9 (1).....

ولما تيجى عربية الخضار نأخذ خضارنا على قدنا

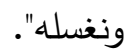

هـ. مرحلة التعلم: وتسمى أيضاً مرحلة الدروس المستفادة

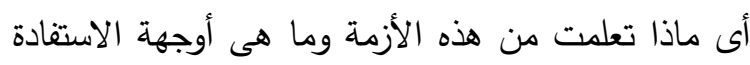
كى نتجاوز مثل هذه المدن فى المرات القادمة. وتم التعرف عليها من خلال سؤال المبحوثات السؤال التالى لثى

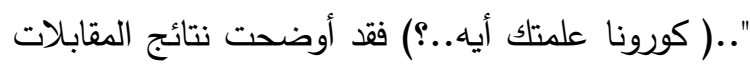

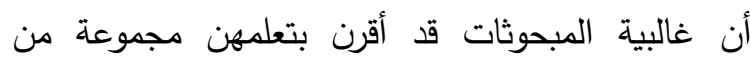
الدروس، وقد تتوعت وتعددت النقاط التى تعلهنها فى أنى أزمة فيروس كورونا كوفيد 9 أوقد تمثلت فى تعلم أهمية

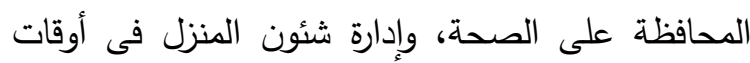

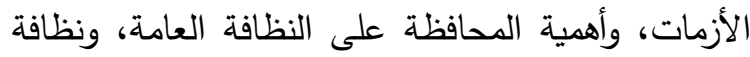
المأكل والمشرب، المواظبة على إعداد الوجبات الصحية،

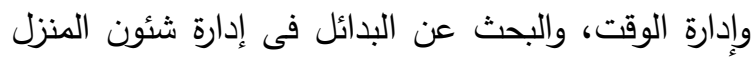

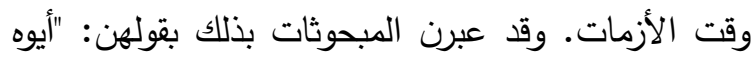

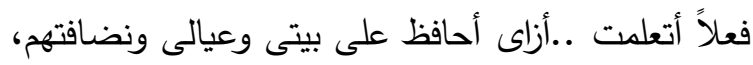
وأتعلدت أزاى تحافظى على نفسك ودايماً لو مؤاخذه تطلع من الحمام تغسلى أيديك.. تطلع للشارع مثلاً تعملى الثلى مصلحة تخشى تغسلى أيديك.. تخلى العيال بردوا يغسلوا أيديهم دايماً بالصابون."، و "اتعلمنا إن الواحدة تحافظ على نفسها تركب عربية تلبس كمامة، بلاش السلام

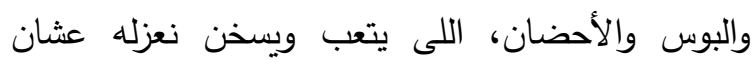
ميضرش غيره"، واتعلمنا نهتم أكتر بعيالنا، بيتنا، بصحتنا، بأكلنا .. اتعلمنا إن حاجة النضافة وعوامل النضافة لازم تبقى فى البيت ع طول وكمان منظفات الحمام مهمة قوى"، وأضافت أخرويات بقولهن "اتعلمنا أنه لانه

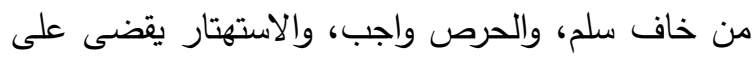

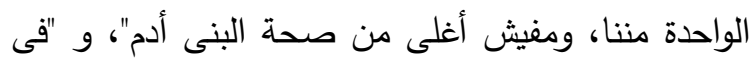

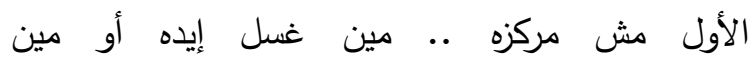
مغسلث؟..لكن دلوقتى لازم، لازم، لازم العيل يغسل إيده

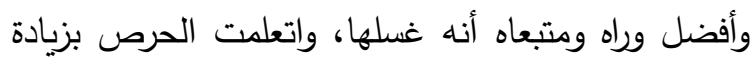

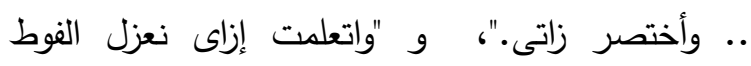

خسارته فى أيام الحظر، مع تطبيقهن لنفس إجراءاتهن وممارستهن فى مرحلة احتواء الأضرار والحد منها، بينما نجد القليل من المبحوثات قد مارسن أمور حياتهن

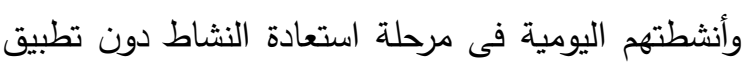
الإجراءات الاحترازية. وتم التعرف على تلك الإجراءات

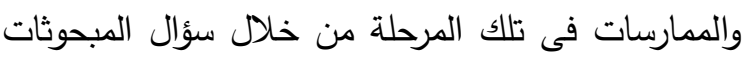
السؤال التالى..(طيب بعد ما فكو الحظر وبدأت ترجع الحياة تانى من ساعتها لغاية دلوقتى أنت عملتى أيه..؟)

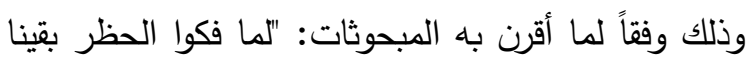
نروح السوق نبيع من تانى بس بحظرنا ومن بعيد ومن لئن غير ما نلامس حد. ومنعنا الاحتكاك نهائى"، و"تقينا نخرج والخوف قل عنا، وبردوا الكمامة والديتول والعيل يغسل أيده كل ما يطلع ويدخل، نفس الحاجات اللى فى وبى الحظر عملناها.. بس بقينا نروح السوق ونبيع ونشترى"، بأل

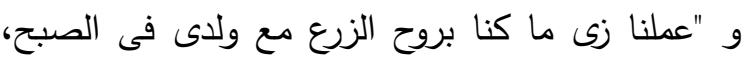
وبقينا نروح .. بس خايفين على نفسنا"، بس بقينا ندور مكنة الميه بالنهار مش بالليل"، و "إيه نعمله أول ما فكوا الحظر والأسواق انتهت كل حاجه .. نزلنا ونزلنا العيال ورجعنا لأسواقنا نبيع ونشترى ونعوض الأيام الللى ربنا ما لأليا يعودها تانى."، و "الناس خلاص أتعودت تعمل كل حاجه من غير كمامة ولا ديتول .. الناس بقت تتساها وكله

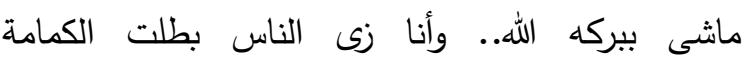
والديتول". وقد عبر بعضهن بفطرتهن عن تلك المرحلة

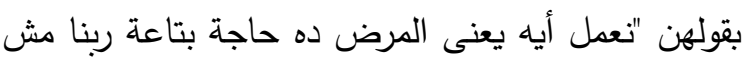
حنقدر نعمل حاجة غير اللى عايزه ربنا، بس خدوا لئل

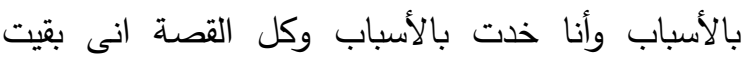
أخرج وأطلع، وفى نفس الوقت أحرص وأكن ألمن العيال مخلتهش يحتكوا بحد خالص .. فضلت قاعدة فى البيت

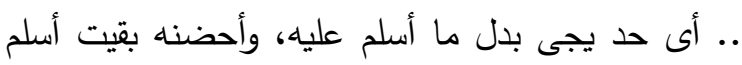

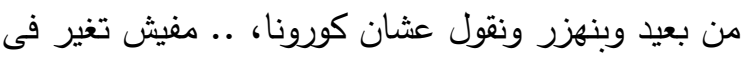

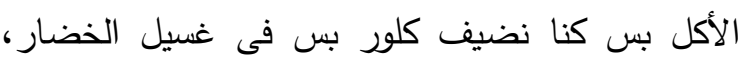


حتى العمالة غير المنتظمة لا أنا ولا عيالى أدونا حاجة، وادينى قاعدية."، و "والله مرمين فى الجبل ولا حد سعى علينا

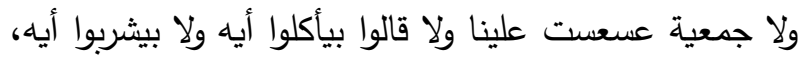
مرمين فى الجبل والحمد لله ولا أى جمعية جاتتا."، و "كانت الوحدة بس -تقصد الوحدة الصحية- بتجبلنا علاج تساعد به الأطفال الصغيرين، وبتجيب لنا دكتورة ريم - تقصد الزائرة الصحية بالقرية - السرنجات اللى بتنزل السخانة للأطفال، وبدير، وكمان مشروع إيفاد عملنا ندوة واحدة عن كورونا وزوعوا علينا ورق عن كيف تقى نفكك من كورونا ورق بس"، و "مفيش حد خبط علينا الباب غير الست ريم الله يسترها وكانت بتقلنا نعمل إيه لو العيل ظهرت عليه السخانة أوجالة

برد"، م • ז: "محدش ساعدنا غير ربنا سبحانه وتعالى".

\section{التوصيات}

\section{فى ضؤ نتائج البحث السابقة يوصى البحث بالأتى:}

ا-أن يركز الإرشاد الزراعى برامجه الإرشادية الزراعية على

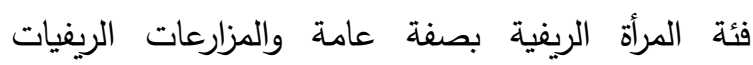
المعيلات بقرى محافظة أسوان بصفة خاصة، وذلك فيما

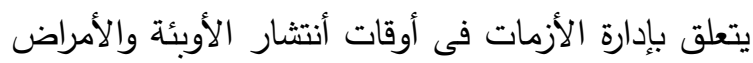
خلال مراحل دورة الأزمة وادارتها.

r-القيام ببرامج تدريبية للمزارعات الريفيات بمحافظة أسوان للتعريف بمراحل الأزمة وكيفية إدارتها فى ظل أنتشار

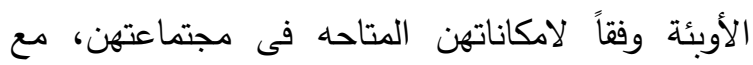

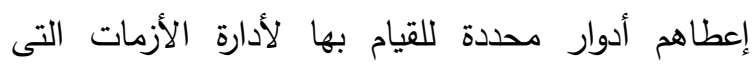
تتعرض لها أسرتها بكفاءة وفاعلية.

r-أن يضع الإرشاد الزراعى برامج إرشادية زراعية

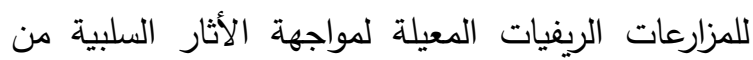
جراء الخوف على الصحة وقت إنتثار الأوبئة فى مقابلة برامج موجهة لادارة شئون المنزل والمزرعة حتى لا يحدث أضرار اقتصادية واجتماعية لديهن.
والصابون وحاجات الللى بنستحمى بيها كل واحد بنخلولوله حاجته لنفسية .. يعنى الوحدة توعت أكتر .. بصراحة الواحدة القلق خلاها تهتم أكتر وتعتتى أكتر .. ربُ ضارة نافعة.. والتليفزيون والإعلام وعانا أكتر ."، بينما نجد أن عدد قليل من المبحوث أقرن بعدم تعلمهن دروساً

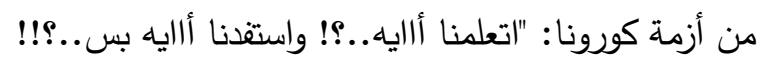
متعلمتش لا طبعاً من كورونا.."، و "هى كورونا فادت حد اله عشان تفيدنى أنا.. دى كانت أيام سوده علينا.. ولولا ربنا وستره ع الغلابه...- سكوت للحظه - الحمد الله ربك بيسترها ع الغلابه."، و "مفيش حاجة حلوة عملتها كورونا لاى حد".

ع - دور جهاز الإرشاد الزراعى والمؤسسات وإلتنموية نحو

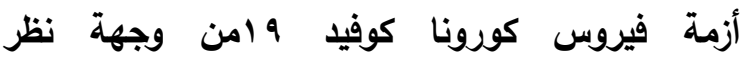
المبحوثات

أتضح من نتائج المقابلات البحثية أن الغالبية العظمى من المبحوثات المشاركات قد أقرن بعدم وجود دور يذكر بـ لجهاز الإرشاد الزراعى والمنظمات التتموية بقربتهم، وأن تلك لك المنظمات لم تقدم أى مساعدات عينية أوفنية خلال دورة الأزمة وإدارتها، بينما ذكرن بعض المبحوثات إلى وجود دور

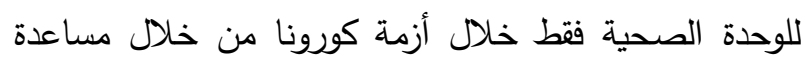
الرائدات الصحيات بالوحدة الصحية لهن فى تقديم معلومات ونصائح عن كيفية الوقاية من الفيروس، وتقديم بعض أدوية السخونة للأطفال. وذلك وفقاً لما ذكرنه رداً على الأسئلة التالية..(فى حد قدم لكم مساعدة فى البلد..؟؟ زى الإششاد الزراعى، وجمعية تتمية المجتمع، والوحدة الصحية، ..؟، وأيه شكل المساعدة اللى قدموها لكم..؟؟) كالآتى: "ولا حاجة .. ولا حاجة .. ولا حاجة ولا قدمولنا ولا ورونا حاجة ولا قدمنا لنا

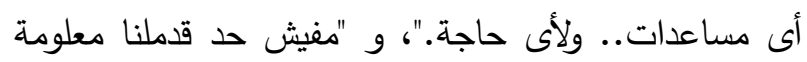

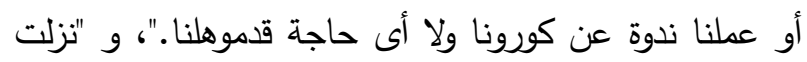
الحكومة . .0منية وثبتتاها على النت ومجتش لنا قالوا لا نستحق". و "قريتنا معزولة غير كل القرى محد ادانا حاجة، 
207محمد عبد العليم على على الرميلى.: دور المزارعات الريفيات المعيلات فى إدارة أزمة جائحة فيروس كورونا (كوفيد -9 ())..........

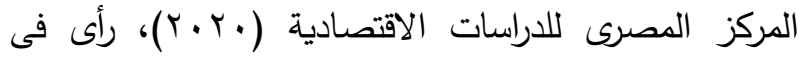

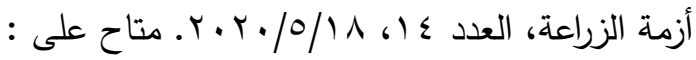

http://www.eces.org.eg/cms/NewsUploads/Pdf/2020_6_16-

2_25_44English\%20Agriculture\%20-\%20dawood.pdf

الهيئة العامة للاستعلامات، (·.r.r)، أهم الإجراءات

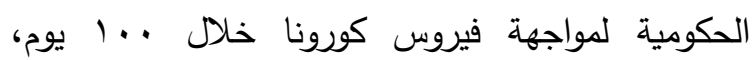

https://www.sis.gov.eg/?lang=ar يونيو متاح على

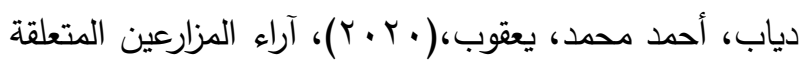

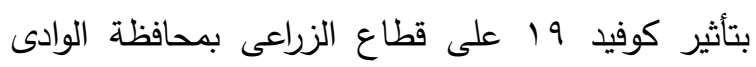

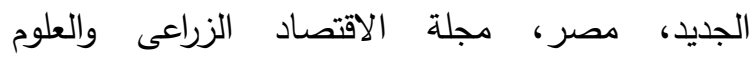

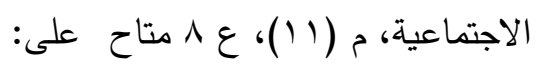

https://jaess.journals.ekb.eg/article_112786_cd37b4e9f0ef002 $28 \mathrm{ee} 4 \mathrm{~b} 5239 \mathrm{cea} 9 \mathrm{c} 8 \mathrm{~b} . \mathrm{pdf}$

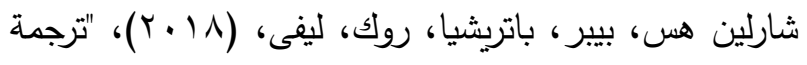
هناء الجوهرى، البحوث الكيفية فى العلوم الاجتماعية، المركز القومى للترجمة، سلسلة العلوم الاجتماعية

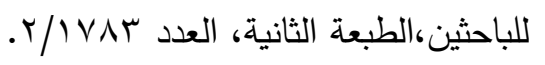

كفال، شتينر(Y (Y. Y)، ترجمة عبد اللطيف محمد خليفة، إجراء المقابلات، المركز القومى للترجمة، سلسلة العلوم

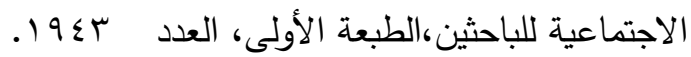

محمود، فاروق (1991 ()، بناء ثقافة وقائية متواصلة، المؤتمر

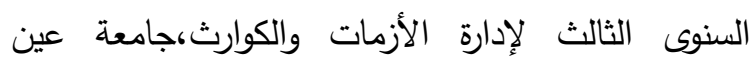

شمس، القاهرة.

مركز البحوث والدراسات متعددة التخصصات ( • • • )، إدارة الأزمات، أساسيات الإدارة الاستراتيجية للأزمات،

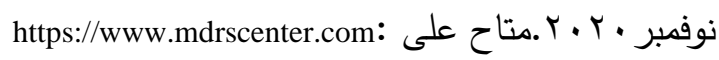
وزار الزراعة واستصلاح الأراضى (Y. V)، مشروع

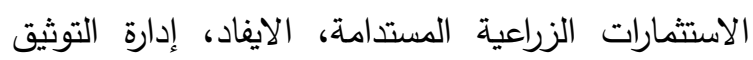

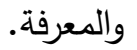 \\ ثانياً: المراجع الأجنبية}

FAO (2020), Gendered impacts of COVID-19 and equitable policy responses in agriculture, food security and nutrition. Rome.

Available

at:
ع-يعتمد الإرشاد الزراعى عند توجيه رسائلة الإرشادية فى

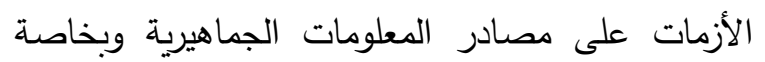

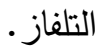

0-إنشاء قسم خاص بإدارة الأزمات بالتنظيم الإرشادى الزراعى المحلى يكون من مهامة التسيق والتعاون والتكامل مع جميع الأجهزة ذات الصلة فى ريف محافظة أسوان للحد من الأثار الصحية والاقتصادية والاجتماعية وقت الأزمات وانتشار الأوبئة على الزراع بشكل عام والمزارعات الريفيات على وجه الخصوص. المراجع

أولا: المراجع العربية أبوفارة، يوسف أحمد (9 . . ب)، إدارة الأزمات مدخل متكامل، الإثراء للنشر والتوزيع، عمان

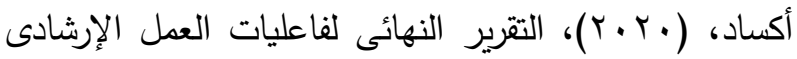

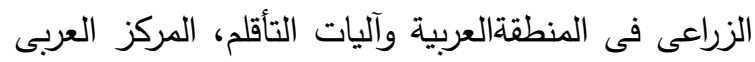

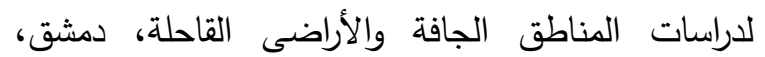
$r \cdot r \cdot / \Lambda / \mu$

الأمم المتحدة، (Y (Y)، تمكين المرأة الريفية ودورها في القضاء على الفقر والجوع وفي التنمية والتحديات

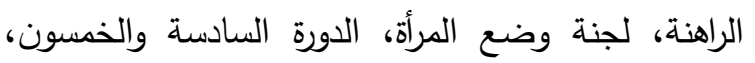
المجلس الاقتصادى والاجتماعى YV فبراير - 9 مارس،

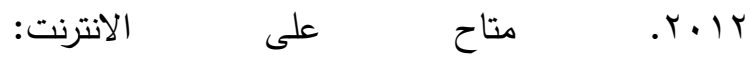
https://undocs.org/pdf?symbol=ar/E/CN.6/2012/3

الأمم المتحدة (·.Y.Y)، اليوم الدولى للمرأة الريفية، 10

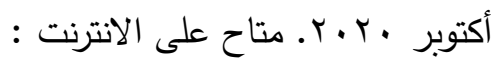
https://www.un.org/ar/observances/rural-women-day

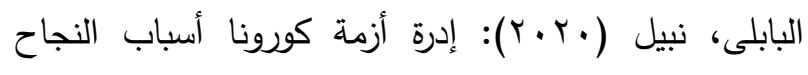
والفشل، المعهد المصرى للدراسات، تقارير سياسية، 17 /https://eipss-eg.org يونيو. متاح على الحملاوى، رشاد (990 ())، التخطيط لمواجهة الأزمات، عشر كوارث هزت مصر، مكتبة عين شمس، مصر 
Creswell JW. Thousand Oaks, California (2007): Sage Publications; Qualitative Inquiry and Research Design: Choosing Among Five Approaches: International Student Edition.

Antonique Koning, Jamie Anderson, Yasmin BinHumam(2020), Women in Rural and Agricultural Livelihoods Facing COVID-19, world bank group(US), blog 27 july 2020, https://www.cgap.org/blog/womenrural-and-agricultural-livelihoods- facing-covid-19

Alison Decker, Patricia Van de Velde, Joao Montalvao (2020), COVID-19: A pivotal moment to support women farmers, blogs.worldbank, |June 03, 2020, https://blogs.worldbank.org/developmenttalk/covid19-pivotal-moment-support-women- farmers
Davis, K., S. C. Babu, and C. Ragasa. (2020), Agricultural Extension: Global Status and Performance in Selected Countries. Washington, DC: International Food Policy Research Institute. Available at: https://doi .org/10.2499/9780896293755.

Kristen Dayton, Jenn Williamson (2020), Women's Empowerment in Agriculture is Essential to COVID-19 survival and Recovery, AGRI LINKS, May 20, 2020, Available at:

https://www.agrilinks.org/post/womens-empowermentagriculture-essential-covid-19-survival-and-recovery

Morse, J. M. (2000). Determining sample size. Qualitative Health Research, 10, 3-5

DiCicco -Bloom B, Crabtree BF (2006). The qualitative research interview. Med Educ.

\title{
ABSTRACT \\ The Role of Women Farmers Breadwinners in Managing the Coronavirus (Covid-19) Pandemic Crisis in One of Wadi Al-Saaida's Villages in Edfu Center, Aswan Governorate
}

\author{
Elramily, M. A. A. A.
}

This research aims to indentity the role of women farmers breadwinners in managing The Covid-19 pandemic crisis in one of Wadi Al-Saaida's villages in Edfu center in Aswan, and the research data had been collected using in-depth interviews with 30 women farmers who were selected from the total number of winners women in the village of Samaha in Wadi AlSa'ida during October and November 2020. The nonquantitative approach was used to analyze the research data, and the most important results of the research were summarized in:

Television is the most important source of hearing and information for the majority of researchers. The most extensive information they have known is how to protect themselves from covid-19 and treatment methods.The majority of women researched had faced economic, social, health, psychological, educational and bad public services due to covid-19 pandemic. The most damaged periods during which the researchers are affected are the periods of worsening the crisis and the decline of the crisis .The majority of the researchers have faced and managed covid-19 pandemic to avoid the crisis and mitigate its effects through a set of practices which they implement them, are: prepare for prevention and face covid-19 by collecting information and identify its damage . and the necessary logistics of purchasing and storing medical supplies and masks, Detergents and disinfectants .The majority of the researchers carry out some daily practices and procedures to contain and reduce the damage of Coved19 pandemic, and its economic damage by saving expenses, relying on their stocks of goods and money, and marketing goods and products from their homes , They reduce social damage by replacing direct communication and visiting parents and neighbors with phone calls. They Reduce the health damage by implementing the precautionary measures taken by the state for her and her family members from complying with hours of curfew, not going to the village markets, avoid gatherings, not attending events and celebrations, and providing meals and healthy foods which resist covid-19 and strengthening immunity. They have daily practices to return to their daily activities, contain the effects of covid-19, and handling what was lost in the curfew, with their application of the same procedures and practice in the stage of containing and reducing the damage, and the majority of the researchers confirmed that there is no significant role for the agricultural extension agency and development organizations in their village during the crisis cycle and management. 